\title{
Footwall topographic development during continental extension
}

\author{
Alexander L. Densmore, ${ }^{1}$ Nancye H. Dawers, ${ }^{2}$ Sanjeev Gupta, ${ }^{3}$ Roman Guidon, ${ }^{1}$ \\ and Tamara Goldin ${ }^{2,4}$ \\ Received 2 December 2003; revised 12 May 2004; accepted 21 May 2004; published 8 July 2004.
}

[1] We examine the progressive development of footwall topography associated with a set of active normal faults in the northeastern Basin and Range Province of the western United States. Fault length and displacement increase monotonically from northeast to southwest in the study area, allowing us to track both variations in footwall morphology with increasing displacement and along-strike changes in morphology on a single fault. We show that patterns of catchment area, footwall relief, and catchment outlet spacing vary predictably and are related to the growth of the range-bounding normal fault array. In this semiarid region, full parsing of footwall drainage area and removal of antecedent topography do not occur until fault arrays grow beyond two crustal-scale segments. Multiple-segment faults with lengths of up to $150 \mathrm{~km}$ have footwall relief that is limited to $\sim 1000 \mathrm{~m}$ in the center of the footwall and that decays to zero at the fault tips over a length scale of $\sim 15 \mathrm{~km}$. We hypothesize that this relatively uniform footwall relief is erosionally limited and reflects the efficacy of surface processes in removing footwall material in the center of the footwall. If the fault array grows by relatively steady propagation of the tips, we suggest that the $15 \mathrm{~km}$ length scale required to reach uniform relief is related to a timescale of relief generation by the fault tip propagation rate. While such propagation rates are poorly known, an average rate of $10 \mathrm{~mm} \mathrm{yr}^{-1}$ would imply footwall relief generation over a timescale of $\sim 1$ Myr. INDEX TERMS: 1815 Hydrology: Erosion and sedimentation; 8010 Structural Geology: Fractures and faults; 8109 Tectonophysics: Continental tectonics — extensional (0905); KEYWORDS: normal faults, topography, fault growth, tectonic geomorphology

Citation: Densmore, A. L., N. H. Dawers, S. Gupta, R. Guidon, and T. Goldin (2004), Footwall topographic development during continental extension, J. Geophys. Res., 109, F03001, doi:10.1029/2003JF000115.

\section{Introduction}

[2] The topography of tectonically active landscapes is the consequence of geomorphic processes acting on the time-integrated tectonic displacement field. However, despite numerous studies of the interactions between tectonics and erosion, development of predictive models of the topographic response to tectonic activity has been problematic, in part because it is generally difficult to determine the displacement field associated with growing structures. Ideally, we require a system in which topography evolves in response to a simple displacement field over a single active structure and in which snapshots of the structure and the landscape are available at different stages of topographic development [e.g., Hetzel et al., 2004].

[3] Studies of the scaling relationships of normal faults have established a clear proportionality between fault length

\footnotetext{
${ }^{1}$ Institute of Geology, Department of Earth Sciences, Eidgenössische Technische Hochschule Zürich, Zurich, Switzerland.

${ }^{2}$ Department of Earth and Environmental Sciences, Tulane University, New Orleans, Louisiana, USA.

${ }^{3}$ Department of Earth Science and Engineering, Imperial College, London, UK.

${ }^{4}$ Now at Department of Geosciences, University of Arizona, Tucson, Arizona, USA.

Copyright 2004 by the American Geophysical Union. 0148-0227/04/2003JF000115
}

and displacement [e.g., Cowie and Scholz, 1992a; Dawers et al., 1993; Schlische et al., 1996], and this provides a simple, convenient framework for considering the direct relationships between tectonic displacements and topographic evolution. Interpretation of the fault displacement length data has led to the recognition that crustal-scale normal fault arrays grow by a combination of displacement accumulation, lateral tip propagation, and linkage of adjacent segments [e.g., Anders and Schlische, 1994; Cowie, 1998; Morewood and Roberts, 1999; Dawers and Underhill, 2000; McLeod et al., 2000; Cowie et al., 2000]. These processes of fault growth have found wide application in understanding the rates and patterns of subsidence in hanging wall basins [Gupta et al., 1998; Morley, 1999; Cowie et al., 2000; McLeod et al., 2000]. What is much less clear is the effect of fault growth on the evolution of associated mountain ranges and on patterns of denudation. Does the proportionality between fault length and displacement give rise to a similar relationship between fault length and topographic relief? If not, when and how does the surface topography become an imperfect reflection of the underlying tectonic displacement field? Harbor [1997], for example, recognized that analysis of active normal faults with a range of total displacements could be used to generate a composite model of footwall denudation; however, he did not consider lateral fault growth and the consequences for along-strike variations in denudation and sediment supply. 


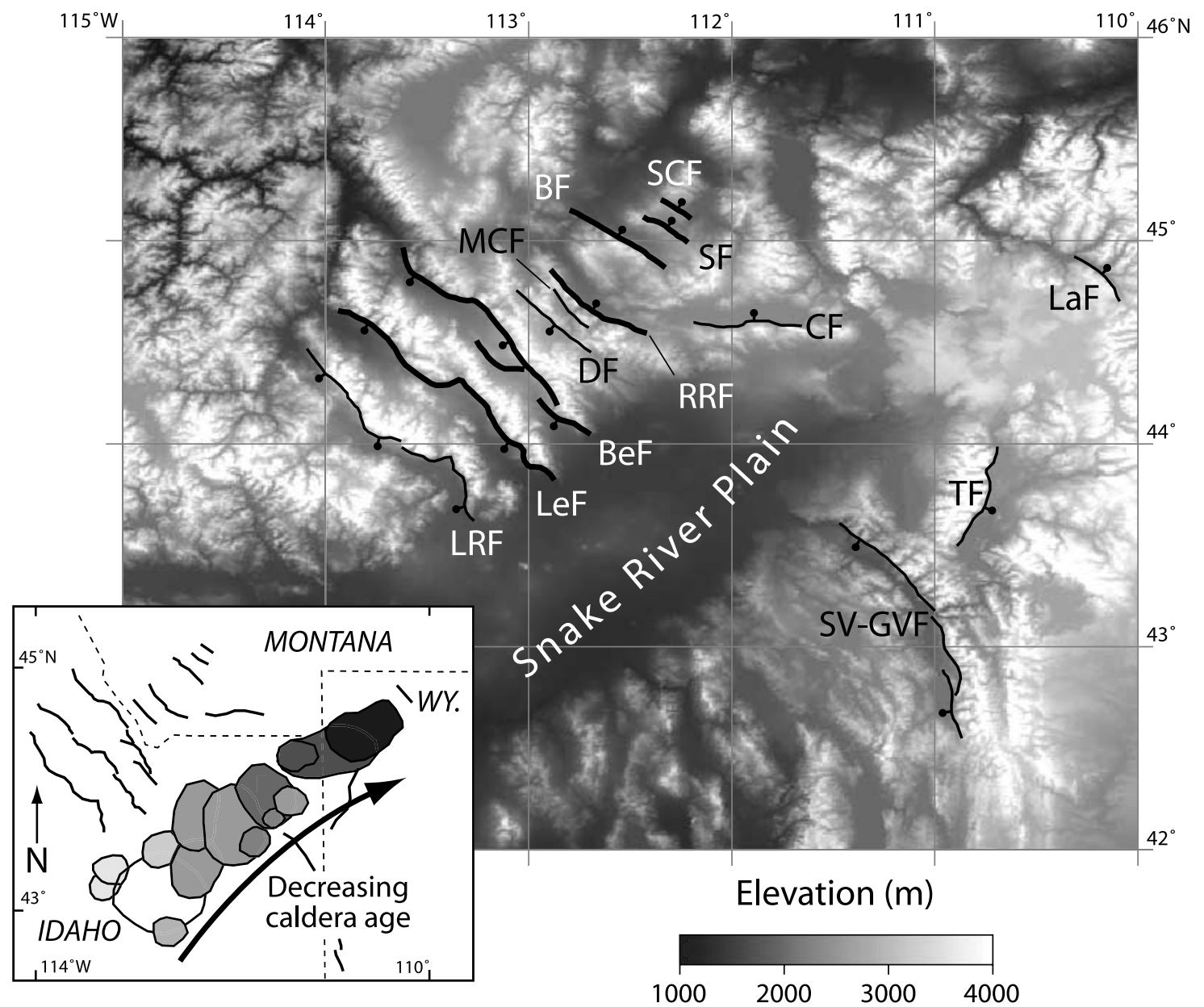

Figure 1. Location map showing active faults in the northeastern Basin and Range Province, western United States, for which we have length and throw estimates. The faults analyzed are shown in bold. Ball and ticks are on the hanging wall block. The inset shows the spatial migration of volcanic calderas associated with the Yellowstone hot spot (M. Anders, personal communication, 2004). Caldera age varies from oldest (white) in the southwest to youngest (black) in the northeast. Fault names are as follows: BeF, Beaverhead fault; BF, Blacktail fault; CF, Centennial fault; DF, Deadman fault; LaF, Lamar fault; LeF, Lemhi fault; LRF, Lost River fault; MCF, Muddy Creek fault; RRF, Red Rock fault; SCF, Stone Creek fault; SV-GVF, Swan Valley-Grand Valley fault; SF, Sweetwater fault; and TF, Teton fault.

Hetzel et al. [2004] argued that small thrust-bounded ranges in northeastern Tibet have suffered minimal erosion and therefore preserve the details of the underlying tectonic displacement field.

[4] Here we explore the relationship between fault growth and topographic evolution by examining the topography of simple ranges formed by displacement on a series of normal faults in the northeastern Basin and Range Province, western United States. We take advantage of two key spatial variations: (1) displacement increases with increasing fault length according to a well-defined linear relationship for our chosen set of faults, which allows us to use fault length as a proxy for time in understanding footwall development; and (2) displacement increases from the tips of each fault toward the strike center [e.g., Cowie and Roberts, 2001], which allows us to use along-strike position as a proxy for time in understanding the response of the footwall to lateral fault growth and tip propagation. Because the faults are active and the regional topography is fairly simple, it is straightforward to recognize, and separate, the topography gener- ated by fault displacement from the inherited prefaulting landscape. We demonstrate that fault growth and displacement accumulation are accompanied by topographic variations that are consistent between different ranges, and we conclude by outlining a predictive model of the evolution of topography during extensional faulting.

\section{Study Area}

\subsection{Regional Setting}

[5] The study area is located at the northeastern margin of the Basin and Range Province, north of the Snake River Plain (Figure 1). Importantly for our study, active extensional faults in this region show a monotonic increase in fault length, from $<20 \mathrm{~km}$ long in the northeast to $\sim 150 \mathrm{~km}$ long in the southwest (Figure 2). This systematic spatial variation in fault length has been previously ascribed to passage of the Yellowstone hot spot and progressive fault activation in its parabolic wake [Anders et al., 1989; Pierce and Morgan, 1990; Anders, 1994]. An advantage for our 


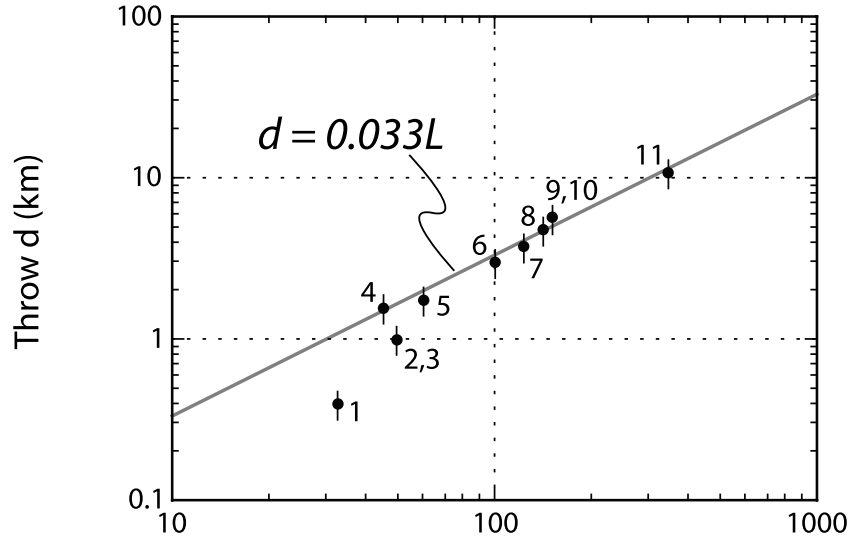

Fault length $L(\mathrm{~km})$

Figure 2. Relationship between fault length and throw (vertical displacement) for active normal faults in the northeastern Basin and Range Province. Fault locations are as in Figure 1 (except for the Wasatch fault in central Utah). The shaded line shows the best-fit linear regression through the data; this relationship is almost identical to that calculated by Schlische et al. [1996] for a range of data over eight orders of magnitude in fault length (note that although Schlische et al. [1996] referred to displacements, much of their normal fault data was reported in terms of throw, as shown here). Because errors in reported throw values are not generally known, error bars show conservative error estimates of $\pm 20 \%$ of total throw. Fault names and sources of data are as follows: 1, Lamar fault, minimum estimate based on offset of Pliocene rhyolite [Love, 1961]; 2, Blacktail fault, maximum estimate (see text) [Haller et al., 2000]; 3, Red Rock fault, maximum estimate (see text) [Haller et al., 2000]; 4, Deadman fault, minimum estimate based on basin thickness and footwall relief [Scholten and Ramspott, 1968]; 5, Centennial fault, minimum estimate based on offset of Huckleberry Ridge tuff [Johns et al., 1982]; 6, Teton fault, estimate from gravity and seismic modeling [Byrd et al., 1994]; 7, Star Valley-Grand Valley fault, maximum estimate based on rotation of volcanic units and an assumed dip of $50^{\circ}$ [Anders, 1990]; 8, Lost River fault, maximum estimate based on offset pre-Tertiary units [Janecke et al., 1991]; 9, Beaverhead fault, maximum estimate based on rotation of volcanic flows and flexural modeling [Rodgers and Anders, 1990; Anders et al., 1993]; 10, Lemhi fault, maximum estimate based on rotation of volcanic flows and flexural modeling [Janecke et al., 1991; Anders et al., 1993]; 11, Wasatch fault, minimum estimate based on fluid inclusion data [Parry and Bruhn, 1987].

study is that regionally exposed Tertiary volcanic units associated with the hot spot have been used to determine tilt rates, onset of deformation, and overall basin geometry on several of the faults, particularly the Beaverhead and Lemhi faults [Rodgers and Anders, 1990; Anders et al., 1993; Anders and Schlische, 1994]. It should be noted, however, that the timing of the onset of activity is poorly constrained, particularly for the shorter faults. Pleistocene and, in some cases, probable Holocene scarps are present along at least portions of all of the faults, indicating continued activity to very recent time [Crone and Haller, 1991; Haller et al., 2000; Janecke et al., 2001].

\subsection{Fault Displacement Length Scaling}

[6] The active normal faults in the circum-Snake River Plain region display a strong positive correlation between cumulative fault throw $(d)$ and total length $(L)$ (Figure 2). The data in Figure 2 include most of the faults in this study, for which lengths and displacements are described below. Also included in Figure 2 are data for several other faults in the northeastern Basin and Range. Error estimates are often not reported in the original studies; where further information has been given or a range of estimates are reported, these are noted in the figure caption. For the data as a whole, throw is linearly related to fault length with a $d / L$ ratio of 0.03 . This systematic increase in fault displacement with increasing fault length permits us to use fault length as a proxy for time in understanding the evolution of mountainous topography.

[7] It is important to note that the larger faults in Figures 1 and 2 are segmented structures that have grown in part by linkage [e.g., Anders and Schlische, 1994]. Crustal-scale normal faults, like those in the Basin and Range, are composed of large-scale segments whose lengths (typically $\sim 10-20 \mathrm{~km}$ ) are likely scaled in some way by the thickness of the seismogenic crust [Jackson and White, 1989]. During fault growth, these segments are linked into a fault array that mechanically acts as a single fault [e.g., Dawers and Anders, 1995] such that the central segments have higher rates of displacement and greater cumulative slip than do the tip segments [Cowie, 1998; Cowie and Roberts, 2001]. While the sites of segment linkage may show small local minima in cumulative displacement [Dawers and Anders, 1995; McLeod et al., 2000], these are not sites of long-term displacement deficit and hence are not sites of greatly reduced footwall topographic elevation or relief [e.g., Anders and Schlische, 1994].

\subsection{Active Faults in the Study Area}

[8] We focus on footwalls adjacent to six presently active, northwest striking normal faults, which from northeast to southwest are the Stone Creek, Sweetwater, Blacktail, Red Rock, Beaverhead, and Lemhi faults (Figure 1). These faults form part of the youngest (Miocene to recent) generation of extensional structures recognized by Janecke et al. [2001] and can be sensibly divided into three groups: singlesegment faults, two-segment faults, and multisegment faults. By comparing footwall topography for different faults of similar length, we reduce the chance that the peculiarities of a single fault will influence our interpretations of footwall development.

\subsubsection{Single-Segment Faults: Stone Creek and Sweetwater}

[9] The northeast dipping Stone Creek and Sweetwater faults (Figure 3a) cut the central Ruby Range of southwest Montana, which is composed largely of Archean metamorphic rocks [Garihan et al., 1982; Ruppel et al., 1993]. The Ruby Range was tilted to the southeast in the footwall of a large, northeast striking normal fault during early to middle Miocene extension (Figure 3a) [Fritz and Sears, 1993; Sears and Fritz, 1998; Janecke et al., 2001, set 4]. In map view the $12-\mathrm{km}$-long Stone Creek fault is partly 


\section{A. Stone Creek fault}

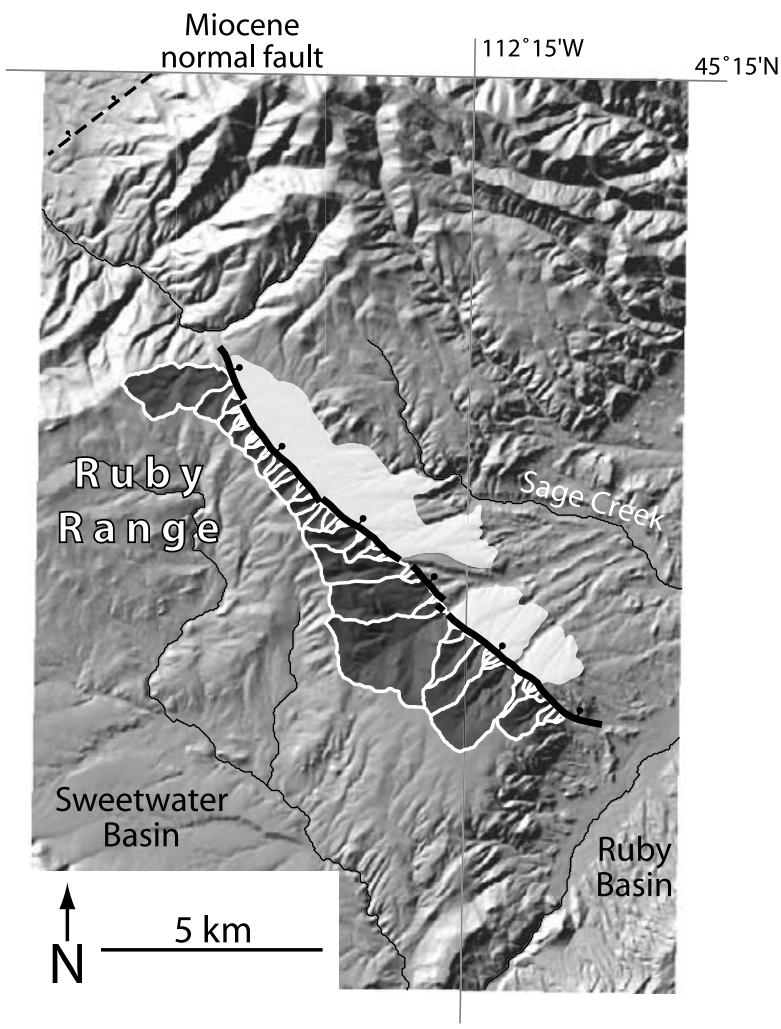

\section{B. Sweetwater fault}

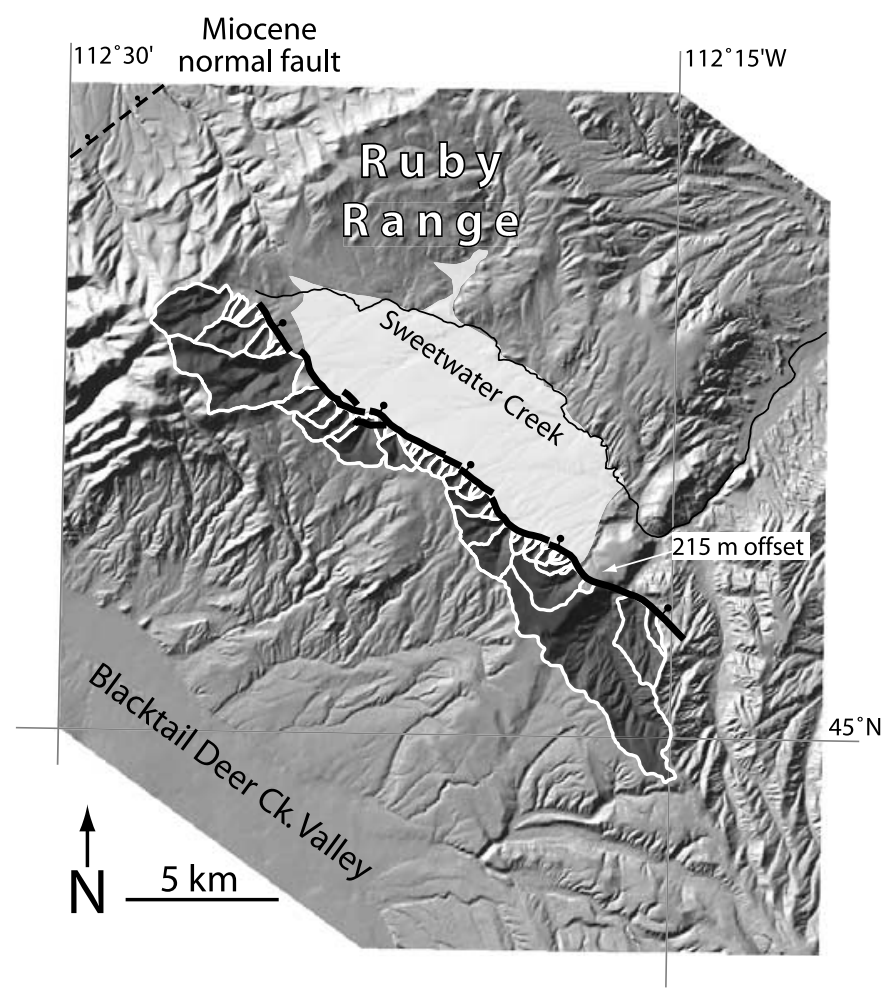

Figure 3. (a) Stone Creek fault. The active fault trace is shown by the bold line; ball and ticks are on the hanging wall block. Footwall catchments, i.e., those that drain across the active fault trace, are shown by dark shading. Thin, discontinuous Quaternary deposits in the hanging wall are shown by light shading. Note the regional southeastward slope and drainage off the Ruby Range. (b) Sweetwater fault. Symbols are as in Figure 3a. Note the outcrops of Timber Hill Basalt on both sides of the fault, which define a $215 \pm 10 \mathrm{~m}$ normal offset across the fault.

coincident with a Proterozoic ductile shear zone that was reactivated as a left reverse oblique slip structure during Laramide deformation [Garihan et al., 1982]. Late Cenozoic normal displacement on the later, brittle Stone Creek fault is shown by deformation of Miocene and Pliocene sediments in the Ruby Basin [Monroe, 1976] and by meterscale scarps in Quaternary deposits. Although the total throw on the Stone Creek fault is unknown, the height of the range front along this fault suggests that it must be at least $250 \mathrm{~m}$.

[10] The 18-km-long Sweetwater fault (Figure 3b) is parallel to the Stone Creek fault and is also partly coincident with a Proterozoic-to-Laramide-aged shear zone [Garihan et al., 1982; Fritz and Sears, 1993]. The presently active trace of the fault is marked by a right-stepping series of 1 - to 2-m-high scarps in alluvium and colluvium and by a series of aligned springs and seeps (Figure 4a). Inception of active deformation postdates emplacement of the $6.0 \pm 0.1 \mathrm{Ma}$ Timber Hill Basalt [Kreps et al., 1992; Fritz and Sears, 1993], which is offset $215 \pm 10 \mathrm{~m}$ at a point $3.5 \mathrm{~km}$ from the southeastern tip of the fault (Figure $3 \mathrm{~b}$ ). The total throw on the Sweetwater fault is unknown, but if the displacement maximum occurs near the strike center of the fault, then the total throw must be at least $215 \mathrm{~m}$.
2.3.2. Two-Segment Faults: Blacktail and Red Rock

[11] The northeast dipping Blacktail fault is $49 \mathrm{~km}$ long and bounds the northeastern side of the Blacktail Mountains (Figure 5a). There is some confusion in the literature over the location, timing, and extent of displacement on the Blacktail fault [Haller et al., 2000]; the map of the presently active fault in Figure $5 \mathrm{a}$ is based largely on our field observations and corresponds to the Northwest and Cottonwood segments of Haller et al. [2000]. Previous workers have reported aligned springs and offset of Quaternary deposits along most of the mapped trace [Stickney and Bartholomew, 1987; Tysdal, 1988; Pierce and Morgan, 1990].

[12] Maximum footwall relief on the Blacktail fault is $800 \mathrm{~m}$, so the total throw must be somewhat greater because of footwall erosion and hanging wall subsidence; Haller et al. [2000] suggested $\sim 1 \mathrm{~km}$ of structural relief. Fritz and Sears [1993] reported that the Blacktail fault offsets the $6.0 \pm 0.1 \mathrm{Ma}$ Timber Hill Basalt by several hundred meters. Significant displacement on the fault must postdate the 2.0 Ma Huckleberry Ridge Tuff, which caps a bajada surface formed of Sixmile Creek Formation near the southern end of Blacktail Deer Creek Valley [Fritz and Sears, 1993; Lonn et al., 2000]. 
[13] The northeast dipping Red Rock fault bounds the northern margin of the Tendoy Mountains (Figure 5b). On the basis of our field observations and on mapping by Lonn et al. [2000], we interpret the active Red Rock fault to be $50 \mathrm{~km}$ long, corresponding to the Timber Butte and Sheep Creeks segments of Haller et al. [2000]. Like the Blacktail fault, the active trace of the Red Rock fault is marked by a series of Quaternary scarps and prominent triangular facts (Figure $4 \mathrm{~b}$ ). Total throw is $\sim 1 \mathrm{~km}$ but is poorly constrained [Haller et al., 2000]. Fritz and Sears [1993] argued that initial surface uplift of the Red Rock footwall is constrained to between 6 and $5.5 \mathrm{Ma}$ on the basis of dated basalt flows that flowed across the footwall, but they did not show supporting evidence for this claim.

A.

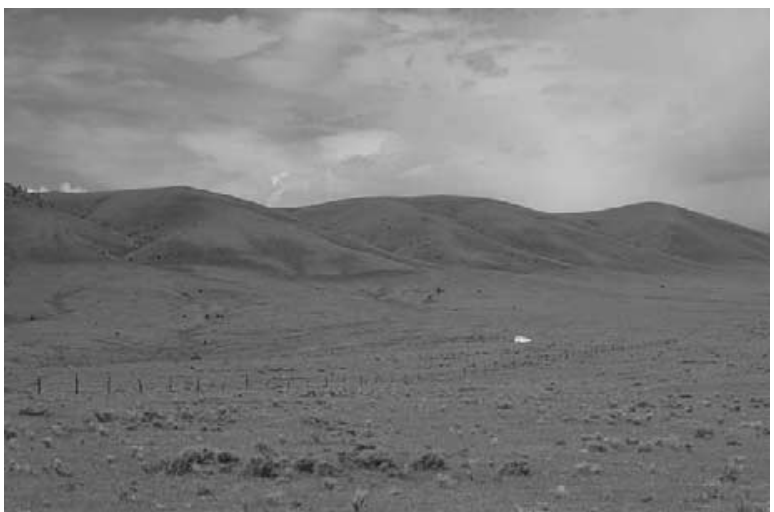

B.

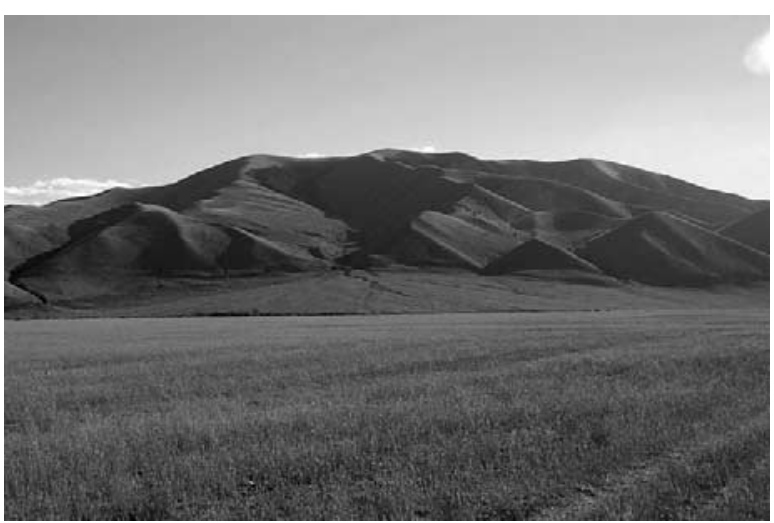

C.

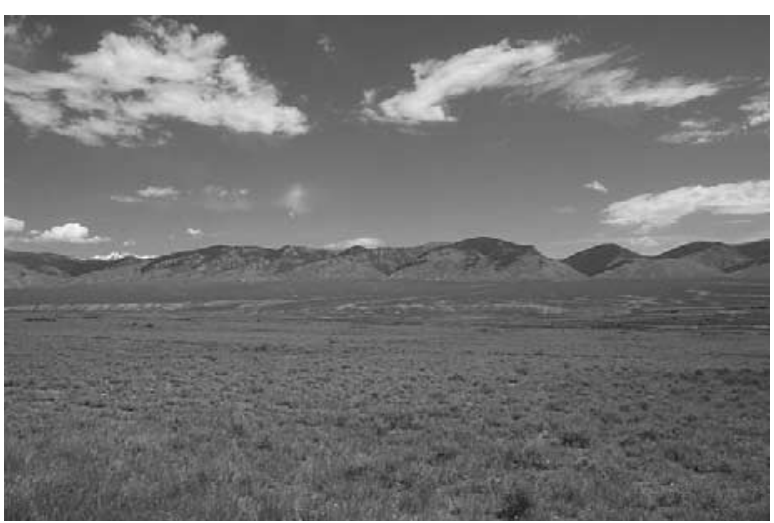

\subsubsection{Multisegment Faults: Beaverhead and Lemhi}

[14] The southwest dipping Beaverhead fault (Figure 6a) is $150 \mathrm{~km}$ long and was subdivided into six segments by Crone and Haller [1991]. Morphologically, the fault is marked by a linear mountain front, well-developed catchment-fan systems, and abundant geomorphic indicators of active base level fall, such as triangular facets and scarps in Quaternary alluvium (Figure 4c). Rodgers and Anders [1990] estimated $2.5 \mathrm{~km}$ of hanging wall subsidence on the Nicholia segment, $\sim 30 \mathrm{~km}$ from the southeastern tip, while Anders et al. [1993] suggested a basin depth of $3.3 \mathrm{~km}$ along the same segment. Anders et al. [1993] also calculated maximum footwall rock uplift of $2.9 \pm 0.7 \mathrm{~km}$ based on tilted volcanic rocks along both the Nicholia and Blue Dome segments. Taken together, these data indicate a total throw of at least $5-6 \mathrm{~km}$ on the Beaverhead fault.

[15] The timing of fault initiation is constrained by observations in both the footwall and hanging wall. The footwall of the Leadore segment contains upper middle Eocene to lower Miocene rocks of the Horse Prairie Basin (Figure 6a) [VanDenburg et al., 1998; Janecke et al., 2001], and Nichols [1976, 1979] inferred local deposition in what would become the Beaverhead footwall in late Miocene time, implying that substantial rock uplift and incision of the footwall must have occurred later. Tilted volcanic rocks in the Blue Dome segment hanging wall are consistent with displacement commencing after $5.4 \mathrm{Ma}$ near the center of the segment and at 3-4 Ma near the Nicholia-Blue Dome relay zone [Rodgers and Anders, 1990] (Figure 6a).

[16] The southwest dipping Lemhi fault (Figure 6b) is also $150 \mathrm{~km}$ long and has been subdivided into six [Crone and Haller, 1991] or seven [Janecke, 1993] segments. Morphologically, the footwall appears very similar to that of the Beaverhead fault. Tilts of volcanic rocks in the footwall of the Howe segment are consistent with $\sim 2.5 \mathrm{~km}$ of footwall rock uplift after deposition of the $6.5 \mathrm{Ma}$ tuff of Blacktail [Anders et al., 1993]. Bouguer gravity lows on the Lemhi and Beaverhead hanging walls are comparable in magnitude [Bankey et al., 1985], suggesting similar depths to prefaulting bedrock. These data imply at least $5-6 \mathrm{~km}$ of total throw on the Lemhi fault. Displacement on the Lemhi fault probably began in the late Miocene, as with the

Figure 4. (a) Field photograph of Sweetwater footwall. The view is to the west, and local footwall relief is $\sim 250 \mathrm{~m}$. The strike center of the fault, which coincides with the smallest footwall catchments, lies $2 \mathrm{~km}$ to the northwest (right), out of the field of view. Note the low scarps along the base of the mountain front, the smooth prefaulting surface on the skyline, and the limited incision into the footwall. (b) Field photograph of Red Rock footwall (Sheep Creeks segment). The view is to the southwest, and local footwall relief is $\sim 800 \mathrm{~m}$. Note the well-developed catchment-fan system and the Quaternary fault scarps (shadowed) along the base of the mountain front. (c) Field photograph of Beaverhead footwall (Nicholia segment). The view is to the northeast, and local footwall relief is $\sim 1000 \mathrm{~m}$. Note the triangular facets, widely spaced catchments, highly variable footwall topography, and extensive hanging wall fans. Local incision of the fans is driven by lateral migration of Birch Creek (middle of photo). 


\section{A. Blacktail fault}

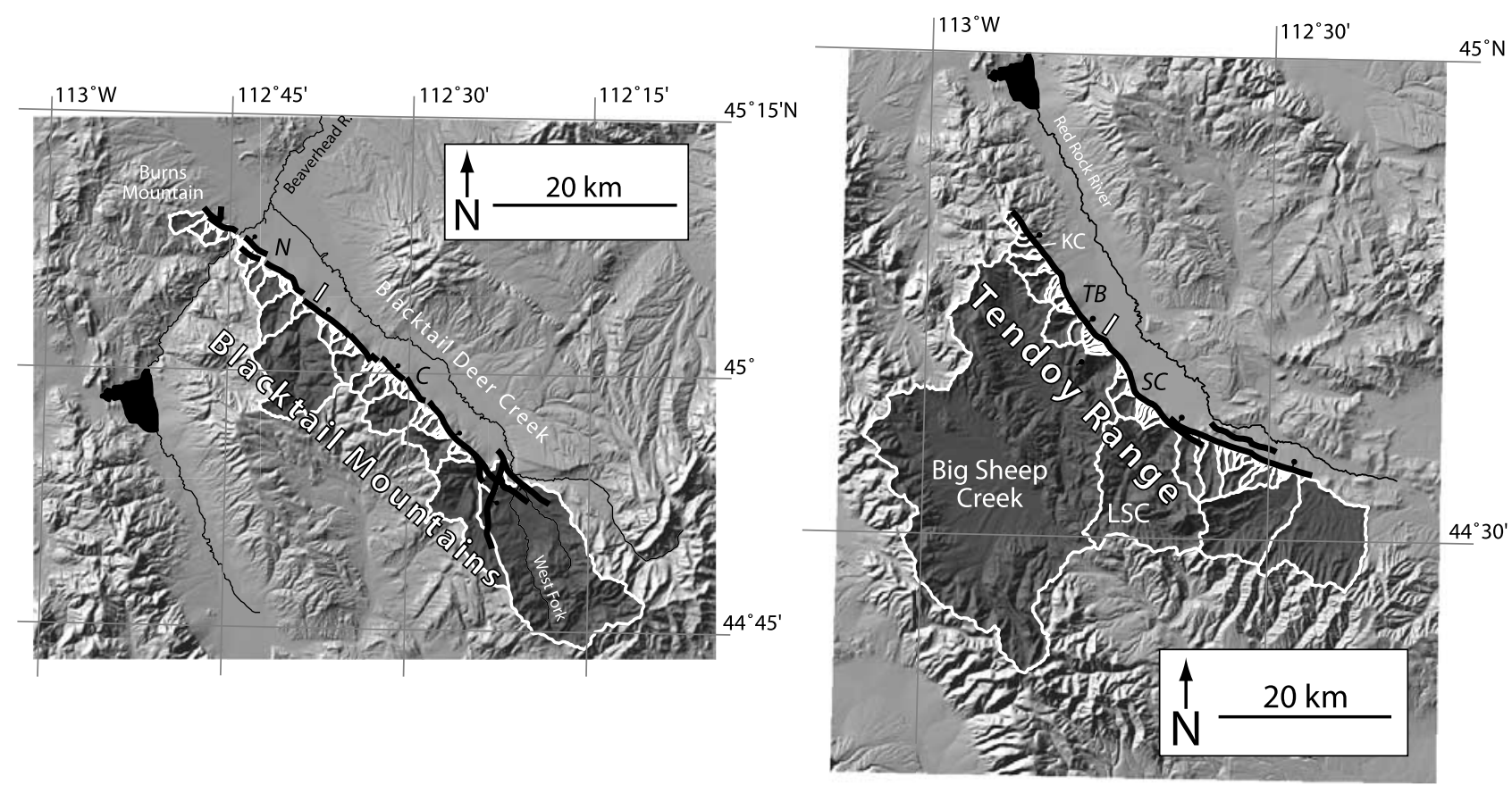

\section{B. Red Rock fault}

Figure 5. (a) Blacktail fault. Symbols are as in Figure 3. The fault trace is modified from Lonn et al. [2000]. Fault segments are from Haller et al. [2000]: N, Northwest segment; C, Cottonwood segment. (b) Red Rock fault. The fault trace is modified from Lonn et al. [2000]. Fault segments are from Haller et al. [2000]: TB, Timber Butte segment; SC, Sheep Creeks segment; KC, Kelmbeck Canyon; LSC, Little Sheep Creek.

Beaverhead fault. Rodgers and Anders [1990] argued that some displacement had already occurred on the southernmost Howe segment before deposition of the $6.5 \mathrm{Ma}$ tuff of Blacktail.

\section{Observations of Footwall Morphology}

\subsection{Methods}

[17] We analyze footwall morphology along each fault using U.S. Geological Survey National Elevation Dataset digital elevation data, with a horizontal resolution of $30 \mathrm{~m}$. These data are relatively coarse, particularly for accurate delineation of the small catchments draining the Stone Creek and Sweetwater footwalls. However, higher-resolution $(10 \mathrm{~m})$ data are available for only part of the study area, so we use the same $30 \mathrm{~m}$ data in order to directly compare results from all footwalls. For each fault we extract the footwall catchments with areas $>0.05 \mathrm{~km}^{2}$ that drain across the map trace of the active fault (shown as the dark shaded areas in Figures 3, 5, and 6). As a first attempt at quantifying footwall morphology, we calculate the simplest possible measures of these catchments: their area, relief, and mean slope.

[18] To assess along-strike variations in footwall relief, we project the extracted footwall catchments onto a faultparallel profile. At each position along the profile we calculate the maximum, mean, and minimum elevations in the fault-normal direction. Footwall relief at each point is the difference between the maximum and minimum elevations. This method is sensitive to small-scale varia- tions in plan-view catchment shape and is not a true measure of individual catchment relief because catchments widen away from the fault, and in places the swath is not exactly fault-parallel. However, the method allows us to derive a continuous footwall relief profile and eliminates the issues inherent in arbitrary selection of an along-strike profile. As a check, we also calculate relief in individual catchments as a function of outlet position along strike; the overall patterns and length scales are very similar to those derived from the profile method.

[19] Because we also suspect that relief in these tectonically active footwalls may be somehow strength limited [e.g., Schmidt and Montgomery, 1995; Densmore et al., 1998; Ellis et al., 1999], implying a relationship between topographic slope and relief, we also calculate the average catchment slopes within the extracted regions. We determine the mean topographic slope for each catchment, using slope values measured over a $3 \times 3$ cell $(90 \times 90 \mathrm{~m})$ window. It is clear that slope estimates using the $30 \mathrm{~m}$ resolution digital elevation model will significantly underestimate true meter-scale slope values, but these estimates provide a useful means of comparing slopes averaged over the scale of individual hillslopes, both along strike and between different footwalls.

\subsection{Catchment Patterns}

\subsubsection{Single-Segment Faults}

[20] Both the Stone Creek and the Sweetwater faults cut across a smooth low-relief surface developed on Archean 


\section{A. Beaverhead fault}

\section{B. Lemhi fault}

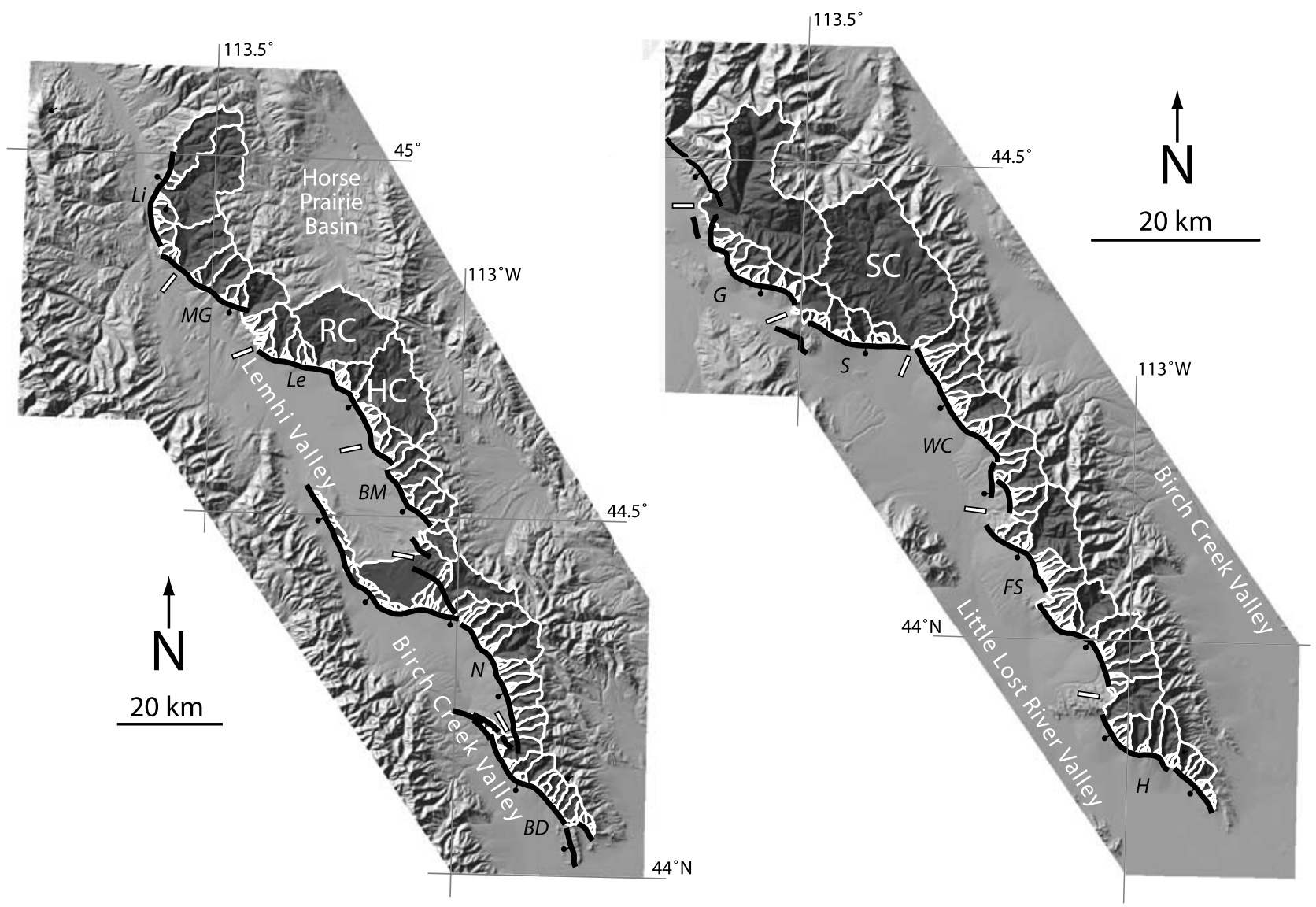

Figure 6. (a) Beaverhead fault. Symbols are as in Figure 3. The fault trace is modified from Skipp [1984] and Janecke et al. [2001]. Note the location of Eocene-Miocene Horse Prairie Basin in the footwall of Beaverhead fault [VanDenburg et al., 1998]. HC, Hawley Creek; RC, Railroad Canyon. Fault segments are from Crone and Haller [1991]: BD, Blue Dome; N, Nicholia; BM, Baldy Mountain; Le, Leadore; MG, Mollie Gulch; Li, Lemhi. (b) Lemhi fault. SC, Sawmill Canyon. The fault trace and segments are from Janecke [1993]: H, Howe; FS, Fallert Springs; WC, Warm Creek; S, Summerhouse; G, Goldburg.

gneiss and tilted to the southeast by Miocene faulting of the Ruby Range block (Figure 3). The faults define small range fronts that are steep and linear near the fault strike centers and become more diffuse and difficult to separate from the inherited topography of the Ruby Range block near the fault tips (Figure 3). Both footwalls show a symmetric map-view catchment pattern in which the smallest catchments occur near the fault strike centers, which we infer to be at or close to the displacement maxima (Figures 7a and 7b). Catchment areas increase progressively toward the fault tips. The location of the smallest catchments near the strike center, close to the inferred displacement maximum, is somewhat counterintuitive. All else being equal, higher displacements near the fault midpoint should lead to higher rates of footwall incision and therefore larger, more widely spaced catchments [Wallace, 1989; Hovius, 1996; Talling et al., 1997]. Both footwalls are composed almost exclusively of Archean gneiss [Ruppel et al., 1993] so that lithology should not be a significant control on catchment size.

\subsubsection{Two-Segment Faults}

[21] The Blacktail and Red Rock footwalls show greater variation in the along-strike distribution of catchment areas than the single-segment footwalls (Figures $7 \mathrm{~d}$ and $7 \mathrm{e}$ ). The largest catchments, the Beaverhead River and Blacktail Deer Creek in the Blacktail footwall and Big Sheep and Little Sheep Creeks in the Red Rock footwall, are antecedent to the faults, based on their regional extent and continuity across several footwall blocks. Of the catchments that have developed in response to fault displacement, no distinct pattern emerges. We interpret this as being due in part to fault tip propagation into areas of significant prefaulting topography. For example, as the northwestern tip of the Red Rock fault propagates into the northern Tendoy Range, preexisting east flowing drainage systems are incorporated into the growing footwall (Figure 5b). Likewise, incorporation of the Sheep Creeks segment into the fault array has added several large catchments to the southeastern end of the footwall (Figure 5b). 
A. Stone Creek fault

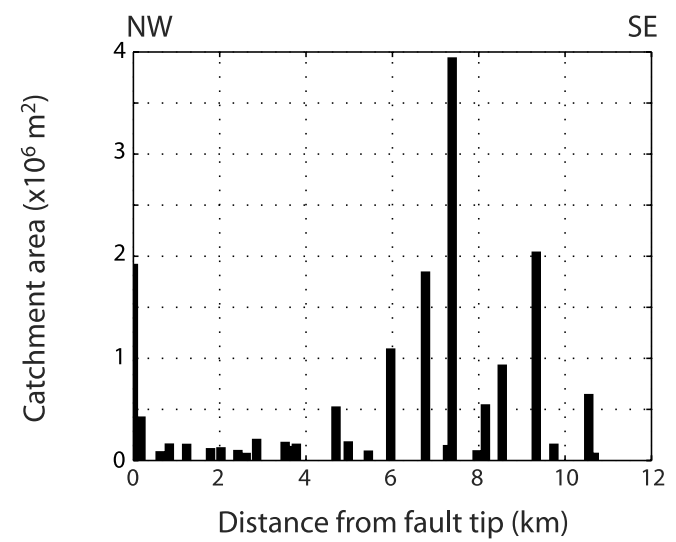

\section{Blacktail fault}

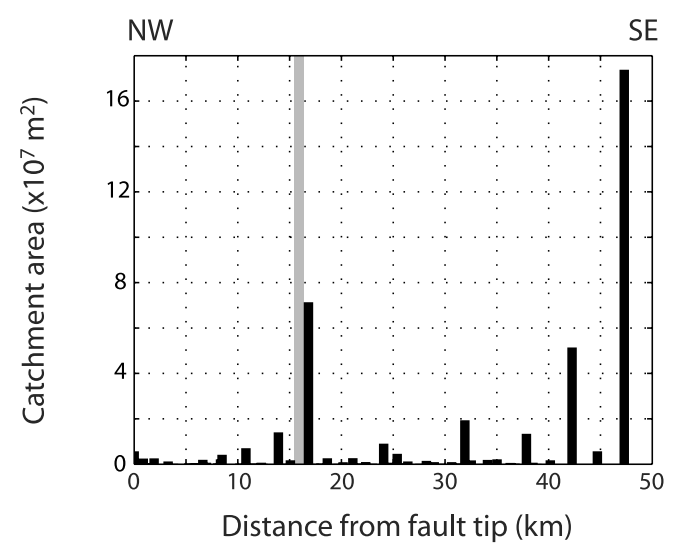

\section{E. Beaverhead fault}

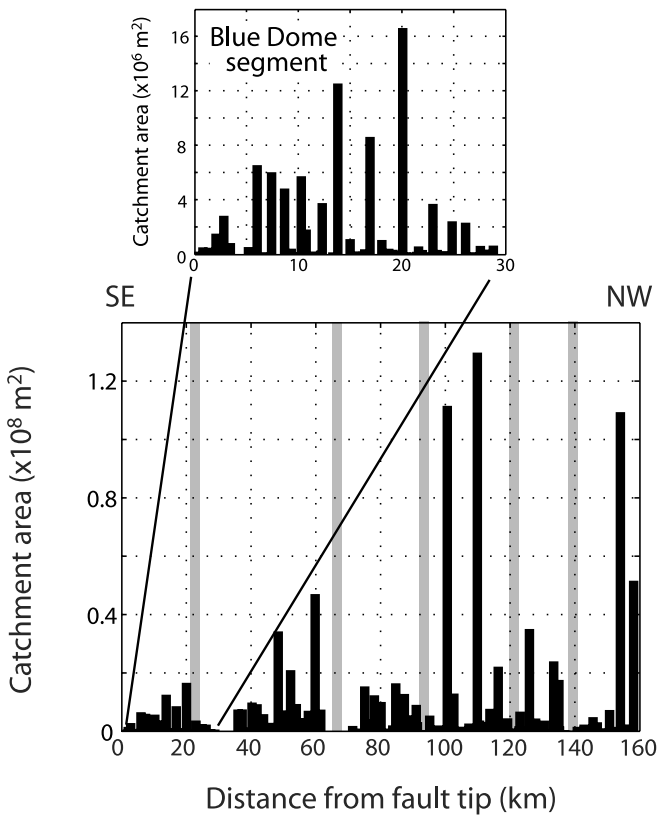

B. Sweetwater fault

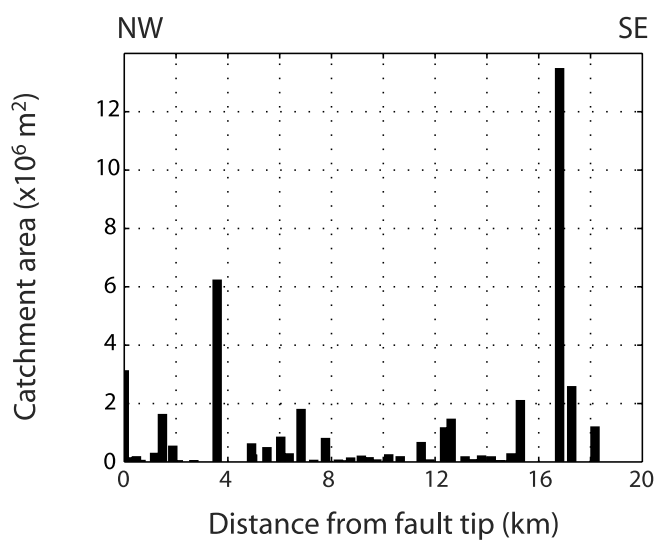

D. Red Rock fault

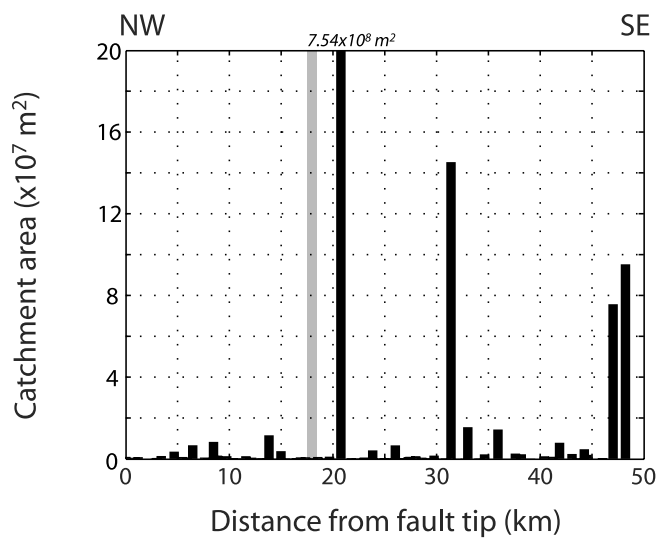

F. Lemhi fault

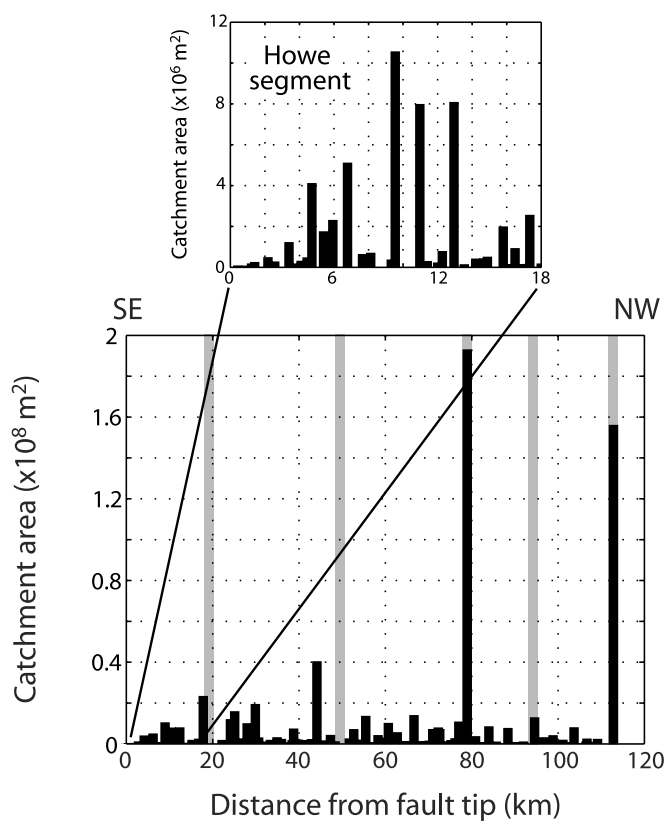

Figure 7. Drainage areas of footwall catchments (see Figures 3-6) as a function of along-strike position for the six faults in the study area. Shaded bars show locations of relay zones between adjacent segments. Insets show catchment areas along Blue Dome (at southeastern tip of Beaverhead fault) and Howe (at southeastern tip of Lemhi fault) segments. 


\subsubsection{Multisegment Faults}

[22] Although we analyze the full $150 \mathrm{~km}$ length of the Beaverhead footwall, we focus on the southern portion of the footwall because the northern end is complicated by the reactivation of an Eocene fault, resulting in considerable inherited topography and basin development (Figure 6a) [Crone and Haller, 1991; Janecke et al., 2001]. Catchment areas in the Beaverhead footwall show a clear variation with along-strike position, both within individual segments and within the fault array as a whole (Figure 7e). Within each segment the largest catchments occur near the strike center of the segment, and catchment size decreases toward the segment tips. Likewise, the largest catchments within the footwall occur close to the center of the array, within the Leadore segment (Figure 6a); curiously, they are associated with the locations of Paleogene basin deposits now exposed within the Beaverhead footwall [Janecke et al., 2001]. Thus the pattern of catchment size along the Beaverhead and Lemhi faults is the opposite of that observed along the single-segment faults. Interestingly, with the possible exception of the Mollie Gulch-Lemhi relay zone, none of the relay zones between adjacent segments coincide with large footwall catchments. This contradicts the widely held belief that relay zones invariably host large drainage basins (see the discussion by Densmore et al. [2003]).

[23] For the Lemhi fault we focus here on only the southern $\sim 115 \mathrm{~km}$ of the footwall, corresponding to the southernmost five segments of Janecke [1993], for two reasons: (1) as with the Beaverhead fault, only the southern end of the fault has a clear gradient in footwall topography decaying to zero at the fault tip and (2) the geometry and displacements on the northernmost two segments on the Lemhi fault are complicated by the presence of a Paleogene normal fault in the footwall [Turko and Knuepfer, 1991; Janecke, 1993]. Overall, the distribution of catchment areas in the Lemhi footwall is similar to that in the Beaverhead (Figure 7f). Catchment areas generally decrease both toward the southern tip of the fault array and toward the tips of individual fault segments. Unlike the Beaverhead footwall, three of the four largest catchments in the Lemhi footwall occur within relay zones (Figure 6b) [Leeder and Jackson, 1993].

[24] The distribution of catchment areas on the Beaverhead and Lemhi faults appears to mimic the expected alongstrike pattern of fault displacement: large catchments near the strike center of the array and the strike centers of individual segments and decreasing catchment size toward segment and array tips.

\subsection{Footwall Relief}

\subsubsection{Single-Segment Faults}

[25] The Stone Creek and Sweetwater faults have similar patterns of low but variable along-strike relief (Figures $8 \mathrm{~b}$ and 8c). In both footwalls the highest relief is found at (1) the northwestern fault tips, where they intersect antecedent catchments that drain the crest of the Ruby Range, and at (2) the southeastern tips, where they intersect the antecedent Sage Creek and Sweetwater Creek catchments. Maximum footwall elevations along both swaths clearly show the southeastward tilting of the Ruby Range footwall that developed during Miocene extension (Figure 3). Relief created by activity on the modern Stone Creek and Sweetwater faults is difficult to separate from this inherited topography
(Figures $8 \mathrm{~b}$ and $8 \mathrm{c}$ ). Short-wavelength variations in footwall relief near the fault strike centers show where catchment incision has occurred in response to fault displacement.

\subsubsection{Two-Segment Faults}

[26] In both the Blacktail and Red Rock footwalls, footwall relief increases monotonically from zero to a maximum of $800-1200 \mathrm{~m}$ over a distance of $\sim 15 \mathrm{~km}$ from the northwestern fault tip and then stays within $\sim 250 \mathrm{~m}$ of this value before decaying again over a similar length scale to the other tip (Figures $8 \mathrm{~d}$ and 8e). In the Blacktail footwall, this symmetrical relief profile is broken by anomalously high relief values near the southeastern tip associated with the antecedent Blacktail Deer Creek catchment (Figure 8d). Because the southeastern tip is situated within $2-3 \mathrm{~km}$ of the west fork of Blacktail Deer Creek, much of the catchment is not actually located within the footwall. Note that we have not included the antecedent Beaverhead River in the calculation of footwall relief for the Blacktail fault; the pattern of relief at the northwestern tip is complicated by the Beaverhead River and by inherited topography of Burns Mountain (Figure 5a).

[27] The long-wavelength structure of footwall elevation in the Red Rock footwall is dominated by the antecedent Big Sheep Creek catchment, which leads to a prominent low in the projected elevation profiles (Figure 8e). Despite this, and despite the inherited topography at the northwestern fault tip, footwall relief along the Red Rock fault is strikingly symmetric (Figure $5 b$ ).

\subsubsection{Multisegment Faults}

[28] The Beaverhead and Lemhi footwalls show the same basic pattern of along-strike relief as the Red Rock fault (Figures $8 \mathrm{f}$ and $8 \mathrm{~g}$ ). Relief increases monotonically from zero at the southeastern fault tips to a maximum of 1000 $1500 \mathrm{~m}$ over distances of $\sim 15 \mathrm{~km}$. Relief is then relatively uniform for up to $100 \mathrm{~km}$ across multiple fault segments, despite systematic variations in maximum and minimum footwall elevations (Figures $8 \mathrm{f}$ and $8 \mathrm{~g}$ ). As mentioned in section 3.2.3, we do not attempt to quantify relief variations at the northwestern ends of these faults because of interference with inherited topography and older generations of normal faults and uncertainty over the location of the active fault tips [Janecke, 1993; Janecke et al., 2001].

[29] In summary, tectonic relief on the shortest faults is partially obscured by inherited prefaulting topography and antecedent catchments. However, the $\sim 1 \mathrm{~km}$ of displacement on the two-segment faults in our study area is sufficient to overcome some of this inherited relief. For multiple-segment faults, footwall relief is approximately uniform along strike, with a monotonic increase in relief in a $\sim 15 \mathrm{~km}$ region adjacent to the fault tips. Surprisingly, the large catchments in the centers of the long fault arrays and the individual segments are not accompanied by high footwall relief; instead, relief appears insensitive to alongstrike position away from the tip regions. We explore the implications of this important observation in section 4.2.

\subsection{Catchment Slopes}

[30] The single-segment Stone Creek and Sweetwater footwalls have an along-strike pattern of mean catchment slopes that is strikingly different from that of relief. The highest mean slopes of $17^{\circ}-20^{\circ}$ coincide with the smallest catchments near the strike centers, where the relief is 
A.

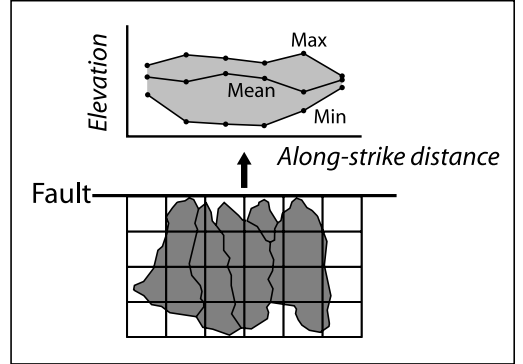

\section{B. Stone Creek fault}

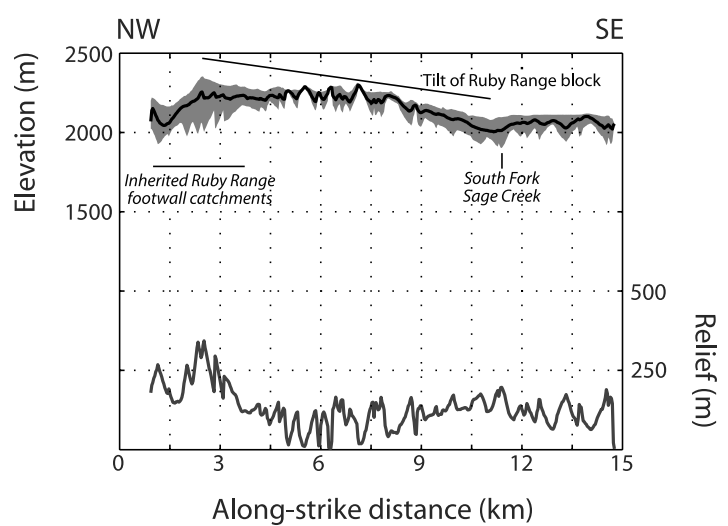

C. Sweetwater fault

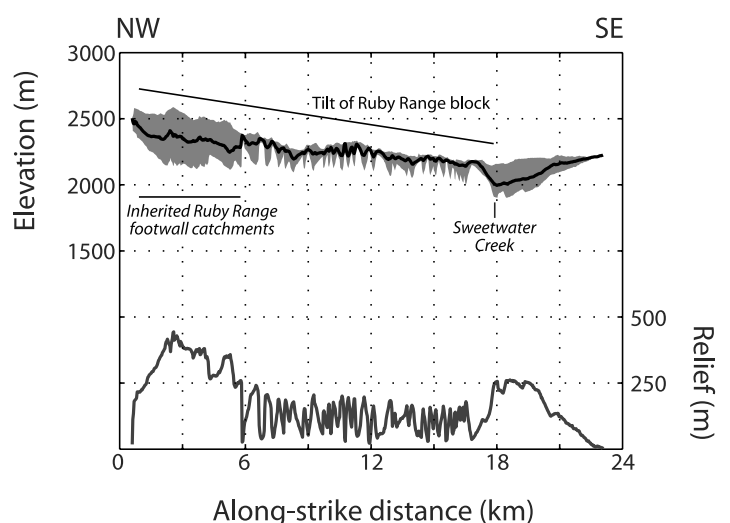

Figure 8. Swath profiles of along-strike footwall relief for the six faults in the study area. (a) Cartoon showing the relief calculation method. Relief is calculated by projecting footwall catchments (see Figures 3, 5, and 6) onto a fault-parallel profile. At each position along the profile the mean, maximum, and minimum elevations are calculated. The relief is defined as the difference between the maximum and minimum elevations at that position. $(b-g)$ Along-strike footwall relief profiles for the six footwalls. Mean elevation (bold line) and elevation range from maximum to minimum (shaded field) are shown on the upper scale of each diagram, while the relief (dark shaded line) is shown on the lower scale. Shaded bars show locations of relay zones between adjacent segments. Major footwall catchments are labeled.

relatively low (Figures 9a and 9b). In contrast, slope values for the two-segment Blacktail and Red Rock footwalls are irregular within $\sim 15 \mathrm{~km}$ of the fault tip but reach maximum values of $25^{\circ}-30^{\circ}$ within a few kilometers of the strike center, corresponding to the maxima in footwall relief (Figures 9c and 9d). Likewise, the multisegment Beaverhead and Lemhi footwalls have highly variable catchment slopes within $15 \mathrm{~km}$ of the tips but relatively constant slopes over much of the footwalls (Figures 9e and 9f). Slopes on the Beaverhead footwall are variable but average $20^{\circ}-$ $25^{\circ}$, whereas those in the Lemhi Range average $28^{\circ}$. The values do not appear to be correlated to relay zones between adjacent segments, suggesting that the along-strike distribution of catchment slopes is insensitive to the fault geometry or along-strike position outside of the $15 \mathrm{~km}$ tip regions.

\section{Discussion}

\subsection{Conceptual Model of Footwall Development During Fault Growth}

[31] The broadly similar morphological observations for footwalls of the same length and segmentation pattern in the study area suggest a systematic, reproducible evolution of footwall erosion during the growth of these fault arrays. We summarize the main features of this evolution at three different snapshots during the fault growth process (Figure 10).

\subsubsection{Stage 1: Single-Segment Faults}

[32] At the first stage of footwall evolution in the northeastern Basin and Range the cumulative tectonic displacement field of the growing fault is superimposed upon an inherited topography with its own drainage system and distribution of relief (Figure 10). Until the tectonic displacements exceed this inherited relief, all aspects of the footwall topography will be dominated by the inherited landscape. The tectonic displacement field first becomes visible near the center of the fault, where the rate of base level fall is greatest; there, small, steep, newly formed catchments incise into the rising footwall. The relief structure of the footwall is a combination of this tectonically driven relief production and the inherited relief. It is important to note that while the antecedent catchments near the tips of growing fault may still have relatively large areas and relief, they will be subject to only low rates of base level change and so may 
D. Blacktail fault

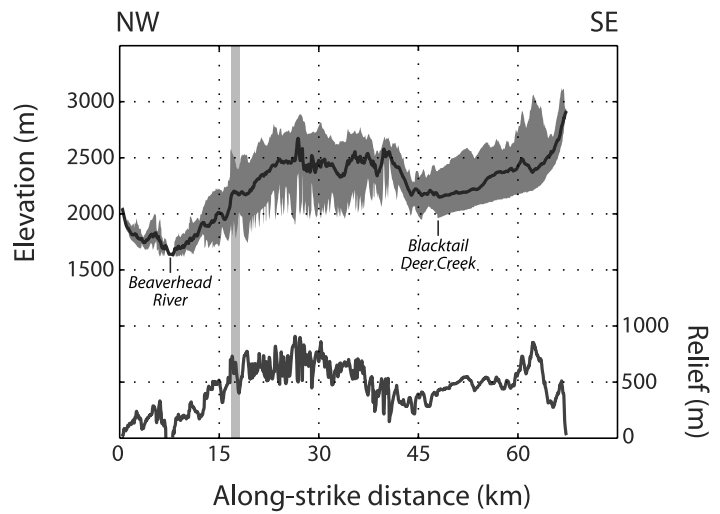

\section{F. Beaverhead fault}

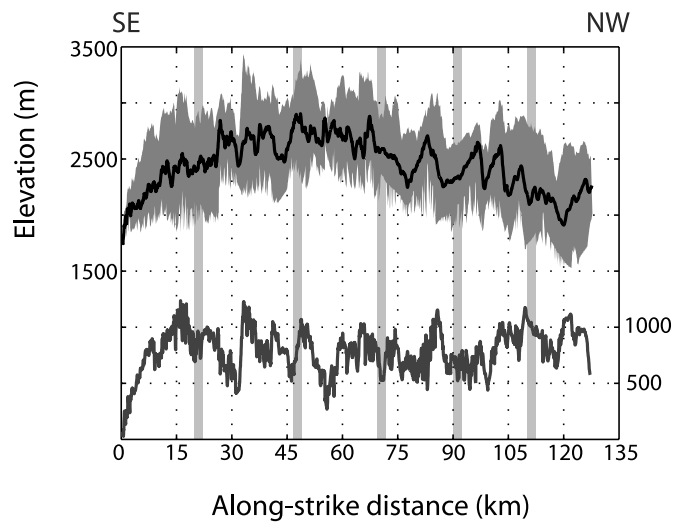

\section{E. Red Rock fault}

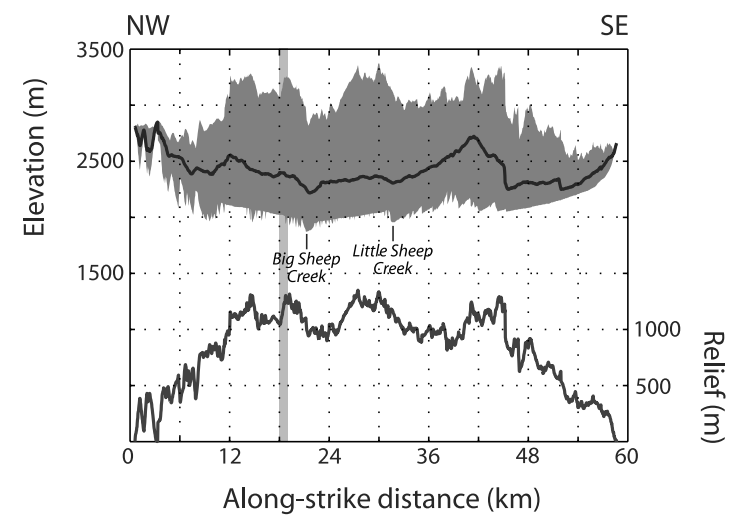

\section{G. Lemhi fault}

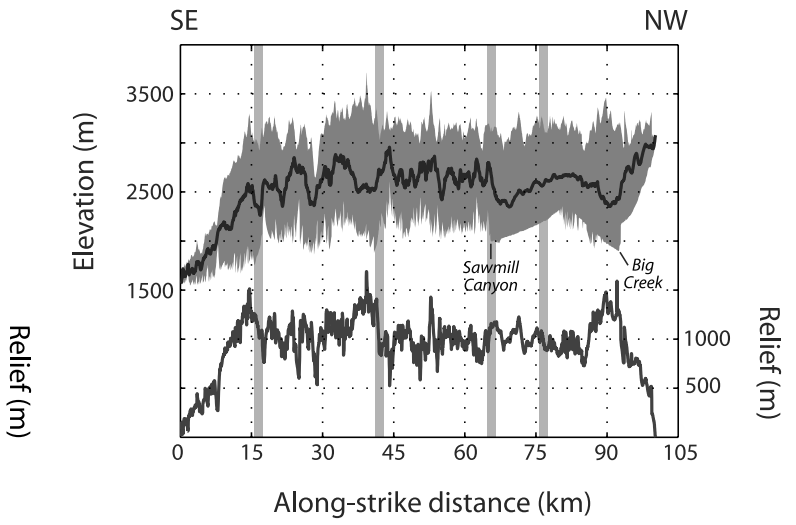

Figure 8. (continued)

not necessarily contribute significant amounts of sediment to the developing basin [e.g., Densmore et al., 2003]. The drainage divide along the range crest is strongly skewed toward the fault in the center of the array, near the displacement maximum. This suggests that, at least locally, high displacement rates, coupled, in these footwalls, with resistant gneiss bedrock, effectively pin the divide close to the fault [Ellis and Densmore, 2003]. In general, the alongstrike patterns of relief, slope, and area are quite different from those that develop later in the evolution of footwalls in the study area.

\subsubsection{Stage 2: Two-Segment Faults}

[33] By the time initial segment linkage has occurred, the highly symmetrical shape of the footwall relief profile has become apparent above the inherited topography (Figure 10). Most importantly, a $\sim 15 \mathrm{~km}$ tip region of monotonically increasing relief has developed. This tip region is distinct from the center of the footwall, where relief reaches an approximately uniform value. However, other aspects of the footwall are still in flux. Antecedent catchments continue to be important in the footwall drainage pattern; in fact, we hypothesize that the footwall may be more likely to intersect regional river systems as the fault array lengthens. Inherited, prefaulting topography, in the form of low-relief areas near the range crest or preexisting ranges near the fault tips, may still be present.

\subsubsection{Stage 3: Multisegment Faults}

[34] In this final stage, all inherited topography has been removed through tectonic displacement and denudation. The available footwall drainage area is fully parsed into consequent catchments that have developed in response to fault activity (Figure 10). The largest catchments occur in the centers of the fault segments and in the center of the fault array, as expected if the displacement profiles on individual fault segments are similar to the displacement profile on the entire fault array [Dawers and Anders, 1995]. Footwall relief and catchment slopes are relatively constant across the center of the fault array and across segment relay zones, implying that the relief is somehow limited beyond the $\sim 15 \mathrm{~km}$ tip region.

\subsection{Implications of Uniform Relief}

[35] The relatively uniform footwall relief in the centers of the larger footwalls demonstrates that unlike displacement, relief does not accumulate continuously during fault array growth. In the northeastern Basin and Range, relief is uniform only for parts of the footwall that are more than $\sim 15 \mathrm{~km}$ from the tip of the fault array, thus setting a characteristic along-strike length scale for relief generation. We hypothesize, on the basis of the relatively constant catchment slopes across most of the footwall, that relief is limited by efficient denudation (Figure 11). Within $\sim 15 \mathrm{~km}$ 
A. Stone Creek fault

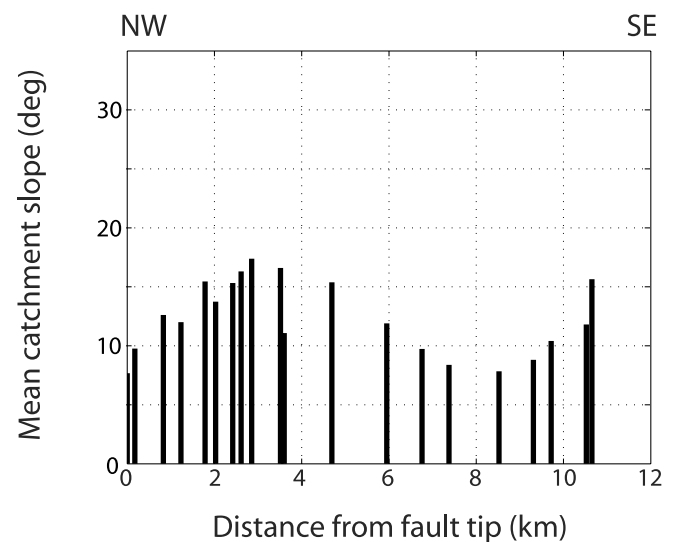

\section{Blacktail fault}

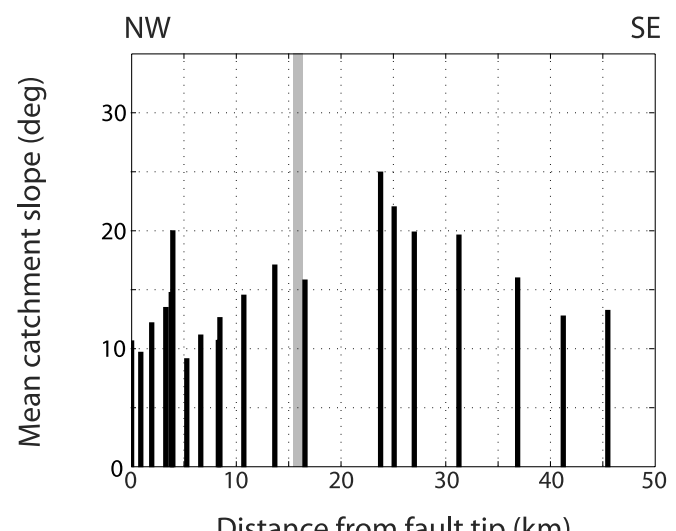

Distance from fault tip (km)

\section{E. Beaverhead fault}

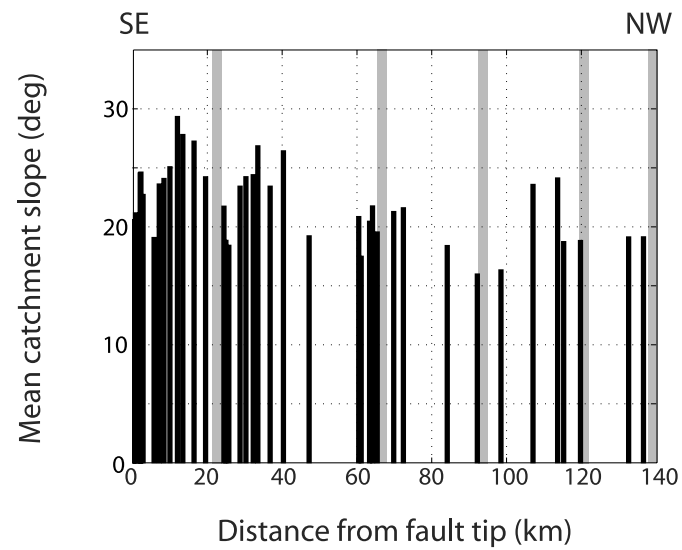

B. Sweetwater fault

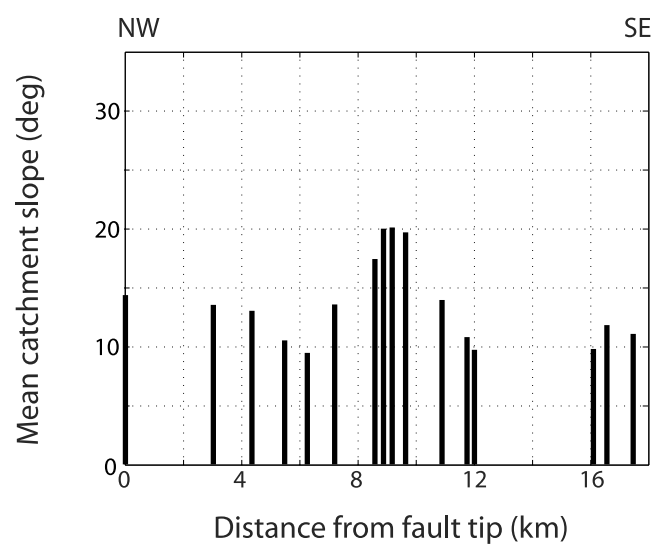

D. Red Rock fault

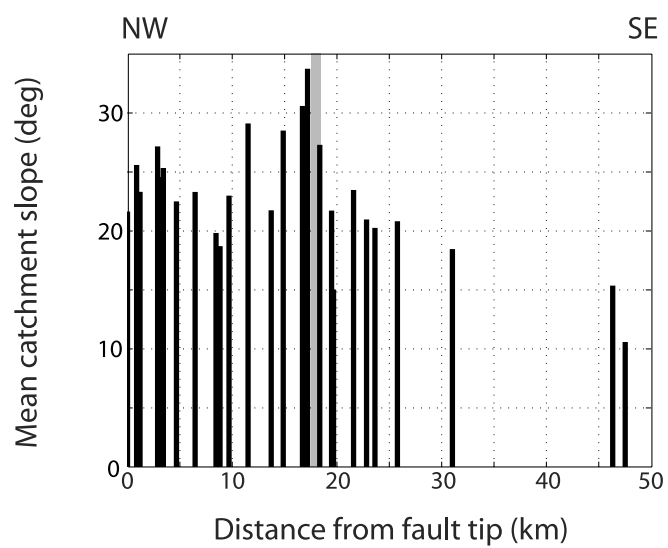

F. Lemhi fault

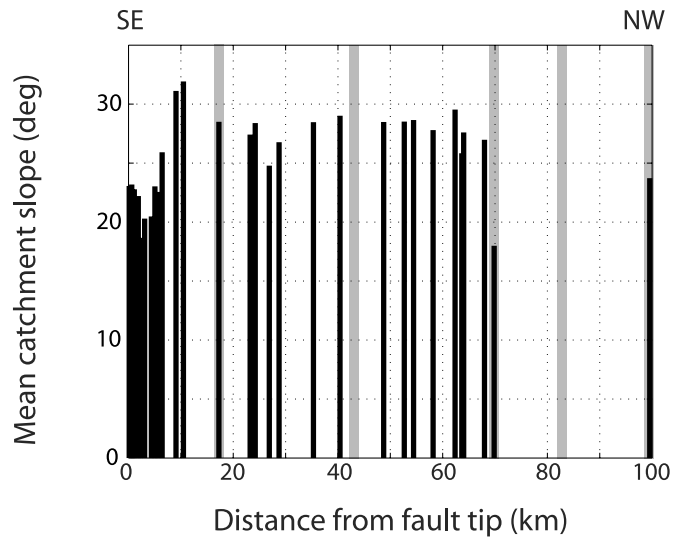

Figure 9. Mean slopes of divide-forming catchments as a function of along-strike position for the six faults in the study area. Slopes are calculated over a $90 \times 90 \mathrm{~m}$ area.

of the fault tips, fault displacement rates are relatively low, and denudation is correspondingly minor, leading to only small differences between the tectonic and actual topography (Figure 11). Beyond this $15 \mathrm{~km}$ length scale, however, the footwall catchment-fan systems are sufficiently evolved so that the tectonic flux of material into the footwall is balanced by the transfer of mass to the adjacent hanging wall. The planar, relatively steep hillslopes within the center of the footwall are consistent with a strength-limited landscape [e.g., Schmidt and Montgomery, 1995; Densmore et 


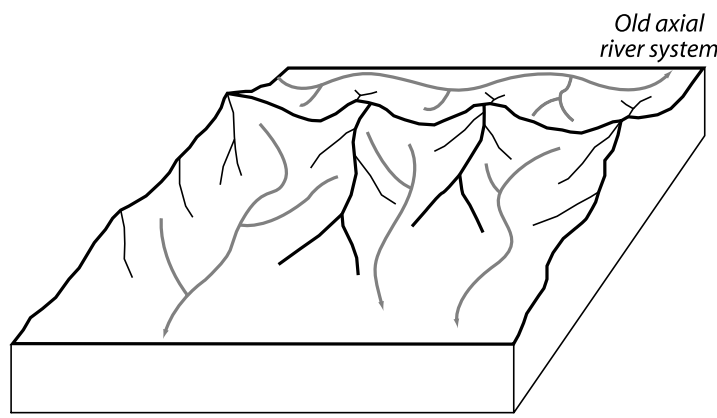

\author{
Stage 0 (pre-faulting) \\ - topography inherited from \\ previous tectonic activity
}
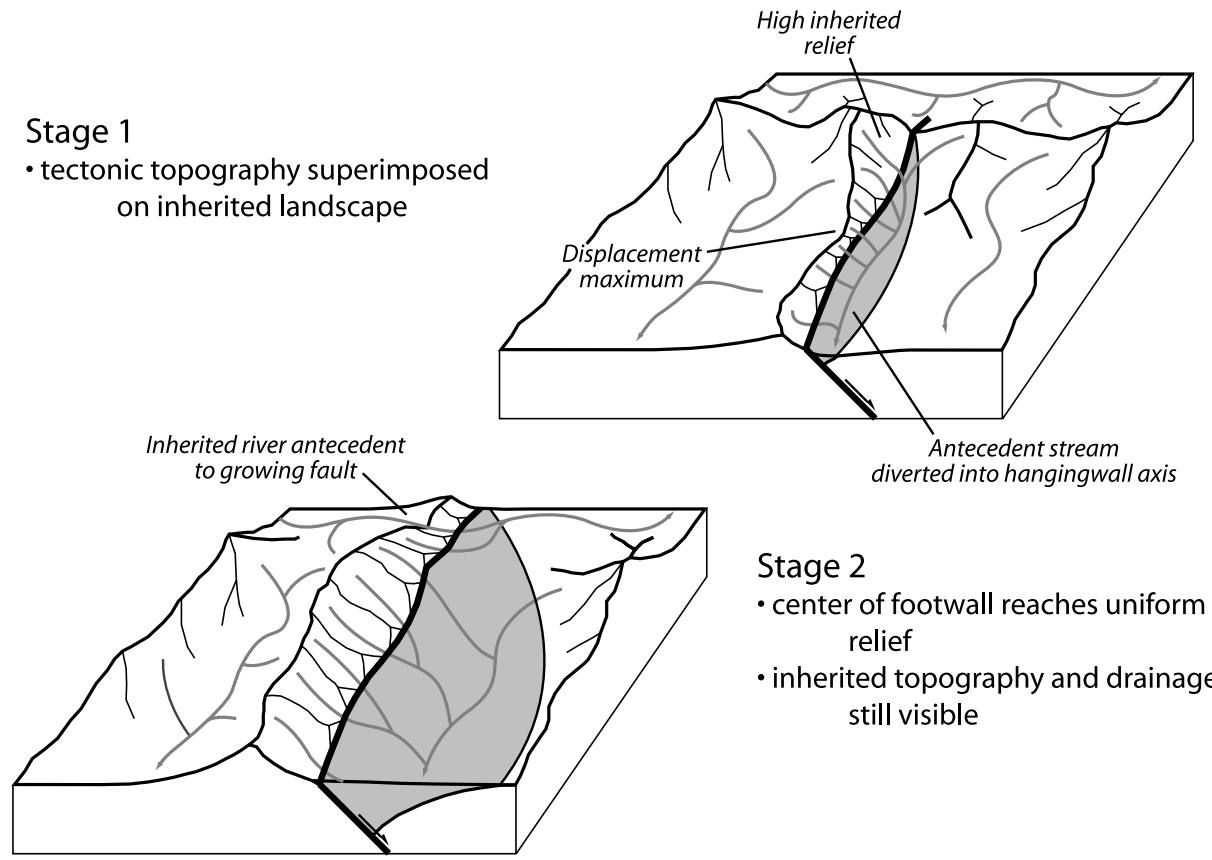

Stage 2

- center of footwall reaches uniform relief

- inherited topography and drainage still visible

Stage 3

- uniform relief away from fault tips

- all inherited topography removed

- footwall drainage area fully parsed

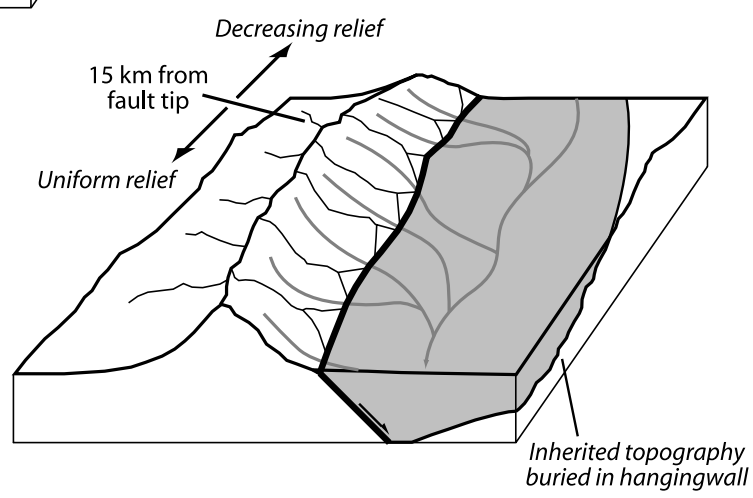

Figure 10. Conceptual model of footwall topographic development in the northeastern Basin and Range. Stage 0 shows the prefaulting topography, which may be inherited from an earlier phase of tectonic activity. Stage 1 shows the early stages of displacement on a single-segment fault; note that antecedent streams are diverted, but not defeated, and that the highest footwall relief is associated with inherited, rather than tectonic, topography. By Stage 2, the footwall has locally achieved steady state relief, but aspects of the prefaulting landscape, such as antecedent rivers, are still present. In Stage 3 the footwall topography is solely the result of denudation acting on the tectonic displacement envelope. A $\sim 15 \mathrm{~km}$ region of decreasing relief toward the fault tip has been established; outside of this region, footwall relief is approximately uniform.

al., 1998]. In this sense, for all points greater than $15 \mathrm{~km}$ from the fault tips, the footwall has reached a statistically steady relief, as defined by Ellis et al. [1999], such that the detailed catchment pattern may vary over time, but the mean elevation and relief of the range will not. This situation is equivalent to a flux steady state of Willett and Brandon [2002].

[36] An important corollary of this hypothesis is that if we can assume that the fault array grows by relatively steady tip propagation, then the $15 \mathrm{~km}$ length scale is equivalent to a 


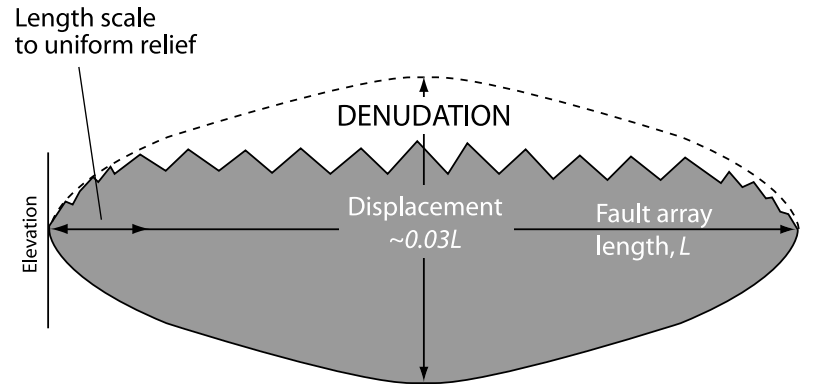

Tip region length scale Fault tip propagation rate

\section{Range-scale response time to uniform relief}

$$
\Rightarrow 15 \mathrm{~km} / 10 \mathrm{~mm} \mathrm{y}^{-1} \sim 10^{6} \mathrm{y}
$$

Figure 11. Schematic cross section of crustal-scale normal fault showing displacement envelope (outer line) and bedrock topography (shaded region). Denudation is the difference between the displacement envelope and the footwall topography. Basin sediments are not shown. Note that in our conceptual model, footwall relief is low within the tip region; beyond this characteristic length scale, relief is approximately uniform along strike. If the fault grows by steady tip propagation, this length scale is related to the time required for relief generation by the fault tip propagation rate.

timescale of relief generation. In other words, the alongstrike distance over which the limiting relief is reached is related to the time required to reach this relief by the fault tip propagation rate (Figure 11). This is a simple but powerful relationship as it provides a possible way of estimating a key timescale in footwall evolution. Unfortunately, very few data exist on rates of fault tip propagation, and true understanding of the timescales required for topographic evolution in the Basin and Range will depend in part on accurate estimates of these rates. At present, we can turn only to scaling arguments [Cowie and Scholz, $1992 \mathrm{~b}$ ] that predict tip propagation rates that are proportional to slip rates and are $\sim 10-100 \mathrm{~mm} \mathrm{yr}^{-1}$ for faults $\sim 50 \mathrm{~km}$ long, broadly in line with very limited field observations [e.g., Morewood and Roberts, 1999]. If an average long-term propagation rate of $10 \mathrm{~mm} \mathrm{yr}^{-1}$ is appropriate for the faults of the northeastern Basin and Range, then $15 \mathrm{~km}$ of tip propagation, and with it the generation of $1 \mathrm{~km}$ of footwall relief, will occur over a timescale of $\sim 1$ Myr.

[37] The hypothesis of strength-limited relief also implies that the only ways to increase footwall relief within the center of the footwall are to (1) increase the rock mass strength or to (2) increase the available space for footwall topography, i.e., the across-strike width of the range. Why should range width not increase with increasing fault displacement? Range width is dependent on two things: the width of the tectonic topography, which is a function of the fault spacing and the elastic properties of the lithosphere [Scholz and Contreras, 1998], and the relative heights of base level and basin fill on either side of the range [Ellis and Densmore, 2003]. Both of these function as external con- trols on the geometry of the footwall and, with the exception of base level in the hanging wall, are not directly dependent on fault displacement. Thus we do not expect range width, or catchment spacing, to increase monotonically with increasing fault displacement, and in fact, cursory inspection of Figure 6 shows that the width of both the Beaverhead and Lemhi Ranges, while variable, is relatively constant along strike, except near the tips.

\subsection{Climatic Influences}

[38] It seems likely that the timescale over which uniform footwall relief is reached should be proportional to the efficiency of surface processes in removing footwall material. Thus we expect a correlation between climatic variables, such as precipitation, and the length or timescales required to reach uniform relief. For example, if the long-term mean precipitation rate were higher in the study area, we would expect that (1) inherited topography should be removed more quickly, (2) the footwalls should reach their uniform relief in less time, and (3) the magnitude of that relief might well be considerably lower [e.g., Whipple et al., 1999; Bonnet and Crave, 2003]. For the same tip propagation rate the length scale to reach uniform relief would then be less than the observed $15 \mathrm{~km}$. Unfortunately, we lack sufficient climatic data in the northeastern Basin and Range in order to investigate the effects of climate on local footwall evolution. Historical mean annual precipitation generally increases from southwest to northeast across the study area, varying from $21 \mathrm{~cm} \mathrm{yr}^{-1}$ in the hanging wall of the Beaverhead fault to $35 \mathrm{~cm} \mathrm{yr}^{-1}$ near the Stone Creek fault [National Climatic Data Center, 2002a, 2002b]. However, the available climate data come from stations located at relatively low elevations in the hanging wall basins. Recent experiments on orographic precipitation in the Wasatch Mountains of Utah, where the local footwall relief is $\sim 1200-1500 \mathrm{~m}$, show enhancement of measured precipitation by up to an order of magnitude between hanging wall and footwall stations [Cheng, 2001; Steenburgh, 2003; Schultz and Trapp, 2003] so that hanging wall observations almost certainly underestimate the actual precipitation that falls on the footwall catchments. Nevertheless, these observations clearly demonstrate the enhancement of orographic precipitation by footwall topography. How the growth of footwall relief initiates well-developed orographic precipitation patterns, thereby enhancing footwall erosion rates, remains a problem of some interest. Additionally, the relationship between footwall aspect, i.e., the direction of fault dip, and delivery of precipitation by prevailing wind patterns is not clear, although it is likely to play a role in the evolution of footwall topography [e.g., Ellis et al., 1999].

[39] The observations of footwall morphology presented here suggest and support, but do not prove, our hypothesis of erosionally limited footwall relief. A powerful test of the hypothesis would be provided by the along-strike distribution of footwall denudation. Our results imply that denudation should vary strongly with position along the fault array, even between areas of similar footwall relief, because of the along-strike variation in displacement rate. Profiles of total denudation and denudation rates, measured using cosmogenic radionuclide or low-temperature thermochronologic 
techniques, may thus shed some light on the precise mechanism and timing of footwall relief generation.

\section{Conclusions}

[40] Analysis of the topography of a set of active normal faults in the northeastern Basin and Range Province allows us to track variations in footwall morphology both along strike and between faults of different lengths. Catchment geometry and footwall relief appear to evolve in a predictable way during the growth of crustal-scale extensional faults in the study area. We propose a three-stage scenario of footwall denudation and catchment development in the northeastern Basin and Range. For single-segment faults, inherited topography dominates the tectonic topography generated by fault displacement. As the fault arrays grow by segment linkage, tectonic topography becomes more apparent, and large, highrelief catchments begin to form in the center of the footwall. Continued growth of the fault array and displacement accumulation leads to a pattern of footwall relief that is relatively uniform along strike, decaying to zero at the fault tips over a length scale of $\sim 15 \mathrm{~km}$. We hypothesize that this limited relief most likely reflects the efficacy of surface processes in removing footwall topography above a certain threshold relief value. If the fault array grows by relatively steady tip propagation, then the tip length scale of $\sim 15 \mathrm{~km}$ should be proportional to the timescale required for generation of steady state footwall relief.

[41] Acknowledgments. This research was supported by grants from the U.S. National Science Foundation (EAR0207569) and the Swiss National Science Foundation (2100-067624). We particularly thank Michael Ellis and Guy Simpson for their insights into landscape evolution and for advice on various methods of quantifying topography. We also thank Philip Allen and Bill Dietrich for useful discussions. Constructive reviews by Nicholas Pinter, Ron Bruhn, and associate editor Darryl Granger as well as comments by Michael Ellis and Kurt Frankel substantially improved the clarity and focus of the manuscript.

\section{References}

Anders, M. H. (1990), Late Cenozoic evolution of Grand and Swan Valleys, Idaho, in Geologic Field Tours of Western Wyoming and Parts of Adjacent Idaho, Montana, and Utah, edited by S. Roberts, Geol. Surv. Wyom Pub. Info. Circ., 29, 15-25.

Anders, M. H. (1994), Constraints on North American plate velocity from the Yellowstone hotspot deformation field, Nature, 369, 53-55.

Anders, M. H., and R. W. Schlische (1994), Overlapping faults, intrabasin highs, and the growth of normal faults, J. Geol., 102, 165-180.

Anders, M. H., J. W. Geissman, L. A. Piety, and J. T. Sullivan (1989), Parabolic distribution of circum-eastern Snake River plain seismicity and latest Quaternary faulting: Migratory pattern and association with the Yellowstone hotspot, J. Geophys. Res., 94, 1589-1621.

Anders, M. H., M. Spiegelman, D. W. Rodgers, and J. T. Hagstrum (1993), The growth of fault-bounded tilt blocks, Tectonics, 12, 1451-1459.

Bankey, V., M. Webring, D. R. Mabey, M. D. Kleinkopf, and E. H. Bennett (1985), Complete Bouguer gravity anomaly map of Idaho, U.S. Geol. Surv. Misc. Field Stud. Map, MF-1773.

Bonnet, S., and A. Crave (2003), Landscape response to climate change: Insights from experimental modelling and implications for tectonic versus climatic uplift of topography, Geology, 31, 123-126.

Byrd, J. O. D., R. B. Smith, and J. W. Geissman (1994), The Teton fault, Wyoming: Topographic signature, neotectonics, and mechanisms of deformation, J. Geophys. Res., 99, 20,095-20,122.

Cheng, L. (2001), Validation of quantitative precipitation forecasts during the Intermountain Precipitation Experiment, M.S. thesis, Univ. of Utah, Salt Lake City.

Cowie, P. A. (1998), A healing-reloading feedback control on the growth rate of seismogenic faults, J. Struct. Geol., 20, 1075-1087.

Cowie, P. A., and G. P. Roberts (2001), Constraining slip rates and spacings for active normal faults, J. Struct. Geol., 23, 1901-1915.
Cowie, P. A., and C. H. Scholz (1992a), Displacement-length scaling relationship for faults: Data synthesis and discussion, J. Struct. Geol., 14, $1149-1156$

Cowie, P. A., and C. H. Scholz (1992b), Growth of faults by accumulation of seismic slip, J. Geophys. Res., 97, 11,085-11,095.

Cowie, P. A., S. Gupta, and N. H. Dawers (2000), Implications of fault array evolution for synrift depocentre development: Insights from a numerical fault growth model, Basin Res., 12, 241-262.

Crone, A. J., and K. M. Haller (1991), Segmentation and coseismic behavior of Basin and Range normal faults: Examples from east-central Idaho and southwestern Montana, U.S.A., J. Struct. Geol., 13, 151-164.

Dawers, N. H., and M. H. Anders (1995), Displacement-length scaling and fault linkage, J. Struct. Geol., 17, 607-614.

Dawers, N. H., and J. R. Underhill (2000), The role of fault interaction and linkage in controlling syn-rift stratigraphic sequences: Late Jurassic, Statfjord East area, northern North Sea, Bull. Am. Assoc. Petrol. Geol., $84,45-64$

Dawers, N. H., M. H. Anders, and C. H. Scholz (1993), Growth of normal faults: Displacement-length scaling, Geology, 21, 1107-1110.

Densmore, A. L., M. A. Ellis, and R. S. Anderson (1998), Landsliding and the evolution of normal-fault-bounded mountain ranges, J. Geophys. Res., 103, 15,203-15,219.

Densmore, A. L., N. H. Dawers, S. Gupta, P. A. Allen, and R. Gilpin (2003), Landscape evolution at extensional relay zones, J. Geophys. Res., 108(B5), 2273, doi:10.1029/2001JB001741.

Ellis, M. A., and A. L. Densmore (2003), Position of the topographic divide as a measure of tectonics, steady-state, and bulk rock strength, Eos Trans. $A G U, 84(46)$, Fall Meet. Suppl., Abstract T22E-05.

Ellis, M. A., A. L. Densmore, and R. S. Anderson (1999), Development of mountainous topography in the Basin Ranges, USA, Basin Res., 11, $21-$ 41.

Fritz, W. J., and J. W. Sears (1993), Tectonics of the Yellowstone hotspot wake in southwestern Montana, Geology, 21, 427-430.

Garihan, J. M., C. J. Schmidt, and L. P. Karasevich (1982), Road log for the Ruby Range, part of the Highland Range, and adjacent intermontane basins, southwest Montana, with emphasis on recurrent tectonic history, in Guidebook of the Seventh Annual Tobacco Root Geological Society Field Conference, edited by P. Beaver, pp. 45-68, Tobacco Root Geol. Soc., Dillon, Mont.

Gupta, S., P. A. Cowie, N. H. Dawers, and J. R. Underhill (1998), A mechanism to explain rift-basin subsidence and stratigraphic patterns through fault-array evolution, Geology, 26, 595-598.

Haller, K. M., R. L. Dart, M. N. Machette, and M. C. Stickney (2000), Data for Quaternary faults in Montana, Open File Rep. 411, 229 pp., Mont. Bur. of Mines and Geol., Butte, Mont.

Harbor, D. J. (1997), Landscape evolution at the margin of the Basin and Range, Geology, 25, 1111-1114.

Hetzel, R., M. Tao, S. Niedermann, M. R. Strecker, S. Ivy-Ochs, P. W. Kubik, and B. Gao (2004), Implications of the fault scaling law for the growth of topography: Mountain ranges in the broken foreland of north-east Tibet, Terra Nova, 16, 157-162, doi:10.1111/j.1365-3121.2004.00549.

Hovius, N. (1996), Regular spacing of drainage outlets from linear mountain belts, Basin Res., 8, 29-44.

Jackson, J. A., and N. J. White (1989), Normal faulting in the upper continental crust: Observations from regions of active extension, J. Struct. Geol., 11, 15-36.

Janecke, S. U. (1993), Structures in segment boundary zones of the Lost River and Lemhi faults, east central Idaho, J. Geophys. Res., 98, $16,223-16,238$.

Janecke, S. U., J. W. Geissman, and R. L. Bruhn (1991), Localized rotation during Paleogene extension in east central Idaho: Paleomagnetic and geologic evidence, Tectonics, 10, 403-432.

Janecke, S. U., J. J. Blankenau, C. J. VanDenburg, and B. S. Van Gosen (2001), Map of normal faults and extensional folds in the Tendoy Mountains and Beaverhead Range, southwest Montana and eastern Idaho, U.S. Geol. Surv. Misc. Field Stud. Map, MF-2362.

Johns, W. M., W. T. Straw, R. N. Bergantino, H. W. Dresser, T. E. Hendrix, H. G. McClernan, J. C. Palmquist, and C. J. Schmidt (1982), Neotectonic features of southern Montana east of 112 degrees 30 west longitude, Rep. 91, Mont. Bur. of Mines. and Geol., Butte, Mont.

Kreps, J., W. J. Fritz, J. W. Sears, and J. M. Wampler (1992), The 6 Ma Timber Hill basalt flow: Implications for late Cenozoic drainage systems and the onset of basin-and-range style faulting, southwestern Montana, Geol. Soc. Am. Abstr. Programs, 24, 22.

Leeder, M. R., and J. A. Jackson (1993), The interaction between normal faulting and drainage in active extensional basins, with examples from the western United States and central Greece, Basin Res., 5, 79-102.

Lonn, J. D., et al. (2000), Geologic map of the Lima $30^{\prime} \times 60^{\prime}$ quadrangle, southwest Montana, Open File Rep. 408, Mont. Bur. of Mines and Geol., Butte, Mont. 
Love, J. D. (1961), Reconnaissance study of Quaternary faults in and south of Yellowstone National Park, Wyoming, Geol. Soc. Am. Bull., 72, $1749-1764$.

McLeod, A. E., N. H. Dawers, and J. R. Underhill (2000), The propagation and linkage of normal faults: Insights from the Strathspey-Brent-Statfjord fault array, northern North Sea, Basin Res., 12, 263-284.

Monroe, J. S. (1976), Stratigraphy, sedimentation, and vertebrate paleontology of the Upper Ruby Basin, Madison County, Montana, M.S. thesis, 302 pp., Univ. of Mont., Missoula.

Morewood, N. C., and G. P. Roberts (1999), Lateral propagation of the surface trace of the South Alkyonides normal fault segment, central Greece: Its impact on models of fault growth and displacement-length relationships, J. Struct. Geol., 21, 635-652.

Morley, C. K. (1999), Patterns of displacement along large normal faults: Implications for basin evolution and fault propagation, based on examples from East Africa, Bull. Am. Assoc. Petrol. Geol., 83, 613-634.

National Climatic Data Center (2002a), Monthly station normals of temperature, precipitation, and heating and cooling degree days 1971-2000 10. Idaho, in Climatography of the United States No. 81, 31 pp., Asheville, N. C.

National Climatic Data Center (2002b), Monthly station normals of temperature, precipitation, and heating and cooling degree days 1971-2000: 24. Montana, in Climatography of the United States No. 81, 51 pp., Asheville, N. C.

Nichols, R. (1976), Early Miocene mammals from the Lemhi Valley of Idaho, Tebiwa, 18, 9-47.

Nichols, R. (1979), Additional early Miocene mammals from the Lemhi Valley of Idaho, Tebiwa, 17, 1-12.

Parry, W. T., and R. L. Bruhn (1987), Fluid inclusion evidence for minimum $11 \mathrm{~km}$ vertical offset on the Wasatch fault, Utah, Geology, 15, 6770.

Pierce, K. L., and L. A. Morgan (1990), The track of the Yellowstone hotspot: Volcanism, faulting, and uplift, U.S. Geol. Surv. Open File Rep., 90-415.

Rodgers, D. W., and M. H. Anders (1990), Neogene evolution of Birch Creek Valley near Lone Pine, Idaho, in Geologic Field Tours of Western Wyoming and Parts of Adjacent Idaho, Montana, and Utah, edited by S. Roberts, Geol. Surv. Wyom. Pub. Info. Circ., 29, 27-38.

Ruppel, E. T., J. M. O’Neill, and D. A. Lopez (1993), Geologic map of the Dillon $1^{\circ} \times 2^{\circ}$ quadrangle, Idaho and Montana, U.S. Geol. Surv. Misc. Invest. Map, I-1803-H.

Schlische, R. W., S. S. Young, R. V. Ackermann, and A. Gupta (1996), Geometry and scaling relations of a population of very small rift-related normal faults, Geology, 24, 683-686.

Schmidt, K. M., and D. R. Montgomery (1995), Limits to relief, Science, 270, 617-620.

Scholten, R., and L. D. Ramspott (1968), Tectonic mechanisms indicated by the structural framework of central Beaverhead Range, Idaho-Montana Geol. Soc. Am. Spec. Pap., 104, 59 pp.
Scholz, C. H., and J. C. Contreras (1998), Mechanics of continental rift architecture, Geology, 26, 967-970.

Schultz, D. M., and R. J. Trapp (2003), Nonclassical cold-frontal structure caused by dry subcloud air in northern Utah during the Intermountain Precipitation Experiment (IPEX), Mon. Weather Rev., 131, 2222-2246.

Sears, J. W., and W. J. Fritz (1998), Cenozoic tilt domains in southwestern Montana: Interference among three generations of extensional fault systems, Geol. Soc. Am. Spec. Pap., 323, 241-247.

Skipp, B. (1984), Geologic map and cross sections of the Italian Peak and Italian Peak middle roadless areas, Beaverhead County, Montana, and Clark and Lemhi Counties, Idaho, U.S. Geol. Surv. Misc. Field Invest. Map, $M F-1601-B$.

Steenburgh, W. J. (2003), One hundred inches in one hundred hours: Evolution of a Wasatch Mountain winter storm cycle, Weather Forecasting, $18,1018-1036$.

Stickney, M. C., and M. J. Bartholomew (1987), Seismicity and late Quaternary faulting of the northern Basin and Range province, Montana and Idaho, Bull. Seismol. Soc. Am., 77, 1602-1625.

Talling, P. J., M. D. Stewart, C. P. Stark, S. Gupta, and S. J. Vincent (1997), Regular spacing of drainage outlets from linear fault blocks, Basin Res., 9, 275-302.

Turko, J. M., and P. L. K. Knuepfer (1991), Late Quaternary fault segmentation from analysis of scarp morphology, Geology, 19, 718-721.

Tysdal, R. G. (1988), Geologic map of the northeast flank of the Blacktail Mountains, Beaverhead County, Montana, U.S. Geol. Surv. Misc. Field Stud. Map, MF-2041.

VanDenburg, C. J., S. U. Janecke, and W. C. McIntosh (1998), Threedimensional strain produced by $>50 \mathrm{~m}$. y. of episodic extension, Horse Prairie rift basin, SW Montana U.S.A., J. Struct. Geol., 20, 1747-1767.

Wallace, R. E. (1989), Geometry and rates of change of fault-generated range fronts, north-central Nevada, J. Res. U.S. Geol. Surv., 6, 637-650.

Whipple, K. X., E. Kirby, and S. H. Brocklehurst (1999), Geomorphic limits to climate-induced increases in topographic relief, Nature, 401, $39-43$.

Willett, S. D., and M. T. Brandon (2002), On steady states in mountain belts, Geology, 30, 175-178.

N. H. Dawers, Department of Earth and Environmental Sciences, Tulane University, New Orleans, LA 70118, USA. (ndawers@tulane.edu)

A. L. Densmore and R. Guidon, Institute of Geology, Department of Earth Sciences, Eidgenössische Technische Hochschule Zürich, CH-8092 Zürich, Switzerland. (densmore@erdw.ethz.ch; roman_guidon@hotmail. com)

T. Goldin, Department of Geosciences, University of Arizona, Tucson, AZ 85721-0077, USA. (tgoldin@geo.arizona.edu)

S. Gupta, Department of Earth Science and Engineering, Imperial College, London SW7 2AZ, UK. (s.gupta@ic.ac.uk) 